\title{
Criticality Experiments with Neutron Flux Traps Containing Voids
}

\author{
S. R. Bierman
}

April 1990

Prepared for the U.S. Department of Energy Office of Civilian Nuclear Waste Management under Contract DE-AC06-76RLO 1830

Pacific Northwest Laboratory Operated for the U.S. Department of Energy by Battelle Memorial Institute 


\title{
DISCLAIMER
}

This report was prepared as an account of work sponsored by an agency of the United States Government. Neither the United States Government nor any agency thereof, nor Battelle Memorial Institute, nor any of their employees, makes any warranty, expressed or implied, or assumes any legal liabiltty or responsibility for the accuracy, completeness, or usefulness of any information, apparatus, product, or process disclosed, or represents that its use would not infringe privately owned rights. Reference herein to any specific commercial product, process, or service by trade name, trademark, manufacturer, or otherwise, does not necessarily constitute or imply its endorsement, recommendation, or favoring by the United States Government of any agency thereof, or Battelle Memorial Institute. The views and opinions of authors expressed herein do not necessarily state or reflect those of the United States Government or any agency thereof.

\author{
PACIFIC NORTHWEST LABORATORY \\ operated by \\ BATTELLE MEMORIAL INSTITUTE \\ for the \\ UNITED STATES DEPARTMENT OF ENERGY \\ under Contract DE-ACO6-76RLO 1830
}

Printed in the United States of America

Available to DOE and DOE contractors from the

Office of Scientific and Technical Information, P.O. Box 62, Oak Ridge, TN 37831; prices availabie from (615) $576-8401$. FTS 626-8401.

Available to the public from the National Technical Information Service, U.S. Department of Commerce, 5285 Port Royal Rd., Springfield, VA 22161.

NTIS Price Codes, Microfiche A01

Printed Copy

\begin{tabular}{|c|c|c|c|}
\hline Price Code & Page Range & Price Code & Page Range \\
\hline $\mathrm{A} 02$ & 1- 10 & A15 & $326-350$ \\
\hline $\mathrm{A} 03$ & $11-50$ & A16 & $351-375$ \\
\hline$A O A$ & 51.75 & A17 & $376-400$ \\
\hline A05 & $76-100$ & A18 & $401-425$ \\
\hline $\mathrm{A} 06$ & $101 \cdot 125$ & A19 & $426-450$ \\
\hline $\mathrm{A} 07$ & $126-150$ & $\mathrm{~A} 20$ & $451-475$ \\
\hline $\mathrm{A} 0 \mathrm{~B}$ & $157-175$ & $\mathrm{~A} 21$ & $476-500$ \\
\hline $\mathrm{A} 09$ & $176-200$ & $\mathrm{~A} 22$ & $501-525$ \\
\hline A 10 & $201+225$ & $\mathrm{~A} 23$ & $526-550$ \\
\hline A11 & $226-250$ & A24 & $551-575$ \\
\hline $\mathrm{A} 12$ & $251-275$ & $\mathrm{~A} 25$ & $576-600$ \\
\hline A13 & $276-300$ & A99 & $601-U_{p}$ \\
\hline A14 & $301-325$ & & \\
\hline
\end{tabular}


CRITICALITY EXPERIMENTS WITH NEUTRON FLUX TRAPS CONTAINING VOIDS

S. R. Bierman

Apri 11990

Prepared for the U.S. Department of Energy Office of Civilian Nuclear Waste Management under Contract DE-AC06-76RLO 1830

Pacific Northwest Laboratory Richland, Washington 99352 


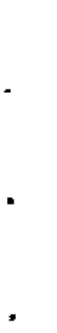




\section{SUMMARY}

A research program was initiated for the U.S. Department of Energy (DOE) by the Sandia National Laboratory Transportation Systems Development Department in 1982 to provide benchmark type experimental criticality data in support of the design and safe operations of nuclear fuel transportation systems. The overall objective of the program is to identify and provide the experimental data needed to form a consistent, firm, and complete data base for verifying calculational models used in the criticality anaiyses of nuclear transport and related systems.

A report, PNL-6205, issued in June 1988 (Bierman 1988) covered measurement results obtained from a series of experimental assemblies $(\pi C-1,2,3$ and 4) involving neutron flux traps. The results obtained on a fifth experimental assembly (TTC-5), modeled after a calculational problem of the Organization for Economic Cooperation and Development (OECD) Nuclear Energy Agency (NEA) Committee on the Safety of Nuclear Installations (CSNI) Working Group, were presented in a report, PNL-6838, issued in October 1989 (Bierman 1989). Criticality experiments to measure the reactivity effect of voiding in neutron flux trap regions are covered in this report. The experiments were performed at the U.S. Department of Energy Hanford Critical Mass Laboratory, operated by Pacific Northwest Laboratory of Battelle Memorial Institute. The work was jointly funded by the DOE Office of Civilian Radioactive Waste Management and the Defense Program.

The measurements were performed in the TTC-3 Experimental Assembly previous ly described as arrangement 214R in PNL-6205 (Bierman 1988). This assembly consisted of four water moderated units of $4.31 \mathrm{wt} \% 235 \mathrm{U}$ enriched $\mathrm{UO}_{2}$ fuel rods arranged in a $2 \times 2$ array and fully reflected by at least $15 \mathrm{~cm}$ of water. Each fuel unit was near equal in size with the fuel uniformly arranged on a $1.891 \mathrm{~cm}$ center-to-center square spacing (1.6 moderator-to-fuel volume ratio). The four fuel units were separated by a $3.73 \mathrm{~cm}$ wide flux trap created by $0.673 \mathrm{~cm}$ thick plates of Boral $96 \mathrm{~cm}$ in length and $45 \mathrm{~cm}$ wide. The plates contained $0.36 \mathrm{~g} \mathrm{~B} / \mathrm{cm}^{2}$ homogeneous $7 y$ dispersed throughout

\footnotetext{
Moral is a trademark product of Brooks and Perkins, Inc.
} 
each plate. Voiding was created in the flux trap region by using $0.63 \mathrm{~cm}$ thick type 6061 aluminum plates uniformly centered between the Boral plates. The critical size of this assembly was determined as voiding was increased from zero in the flux traps to $16.89 \%, 33.78 \%$ and $50.67 \%$. A $17.96 \%$ voiding was also created in the flux traps by replacing the aluminum plates with $1.27 \mathrm{~cm}$ diameter, type 6061 aluminum rods aligned down the center of each flux trap on a $1.891 \mathrm{~cm}$ center-to-center spacing. Measurements also were made to determine the effect that the presence of fuel rods in the flux traps had on the reactivity of the experimental assembly.

Increasing the voiding from zero to $50.67 \%$ in the flux traps by using the aluminum plates results in a 9.5\% decrease in the number of fuel rods required for delayed criticality. Using aluminum rods instead of an aluminum plate increased the number of fuel rods required for delayed criticality by $0.4 \%$ at a voiding of $17.96 \%$. The presence of fue 7 rods in flux traps reduced the critical size of the reference assembly (zero voids) by $10 \%$. 


\section{CONTENTS}

SUMMARY .........................

CRITICALITY EXPERIMENTS HITH NEUTRON FLUX TRAPS

CONTAINING VOIDS .................... 1.1

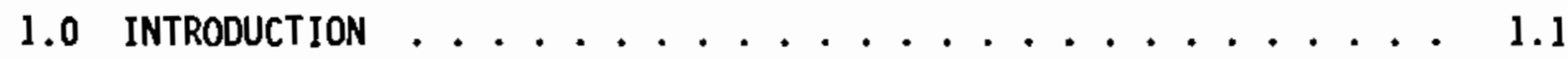

2.0 DESCRIPTION OF EXPERIMENTAL ASSEMBLY . . . . . . . . 2.1

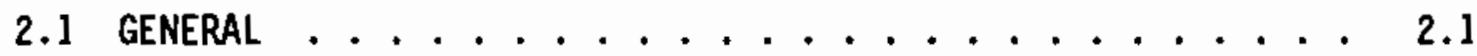

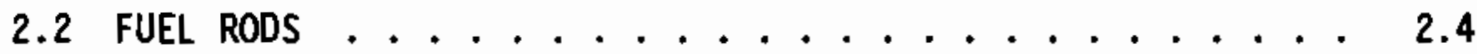

2.3 MODERATOR-REFLECTOR . . . . . . . . . . . . 2.4

2.4 LATTICE PLATES AND SUPPORTS . . . . . . . . . 2.5

2.5 FlUX TRAP PLATES . . . . . . . . . . . . 2.5

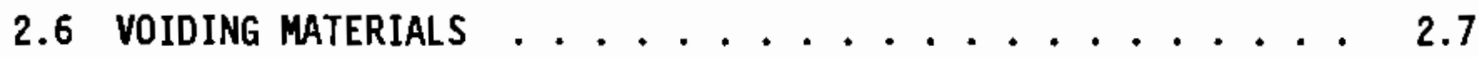

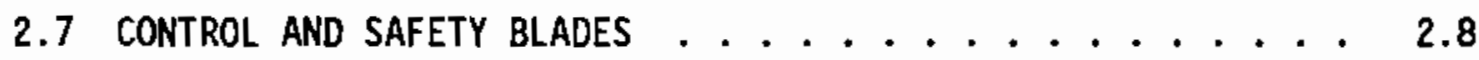

3.0 EXPERIMENTAL MEASUREMENTS AND RESULTS . . . . . . . . . 3.1

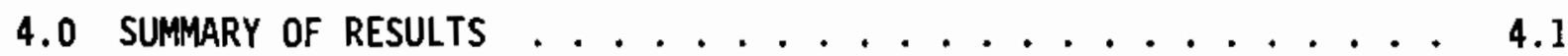

5.0 ACKNOWLEDGMENTS . . . . . . . . . . . . . . 5.1

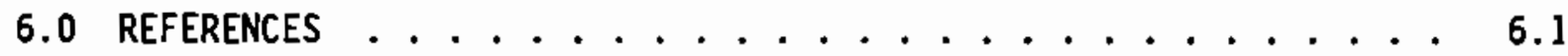

APPENDIX A - DENSITY AND CHEMICAL COMPOSITION OF TYPE 6061 AND

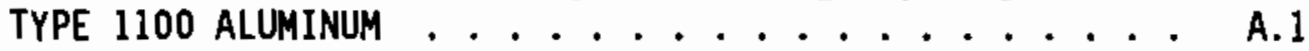

APPENDIX B - TRACE IMPURITIES PRESENT IN THE WATER MODERATOR-
REFLECTOR OF THE EXPERIMENTAL ASSEMBLY $\ldots \ldots . \ldots$

APPENDIX C - IMPURITIES MEASURED IN LATTICE PLATE MATERIAL . . . . c c. 1

APPENDIX D - LOADING DIAGRAMS OF THE EXPERIMENTAL ASSEMBLIES . . . . D. 1 


\section{FIGURES}

1.1 Photograph of Experimental Assembly Partially Loaded with

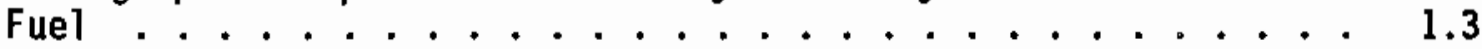

2.1 Experimental System Modified for Use in Experiments . . . . . 2.2

2.2 Description of $4.31 \mathrm{Wt} \% 235_{\mathrm{U}}$ Enriched $\mathrm{VO}_{2}$ Fuel Rods . . . . . 2.3

2.3 Experimental Assembly Elevations . . . . . . . . . . 2.6

3.1 Variation in Critical Size with Flux Trap Voiding . . . . . . 3.3

3.2 Photograph of TTC-3 Assembly with Fuel Rods in the Flux Traps . . . . . . . . . . . . . . . . 3.6

\section{$\underline{\text { TABLES }}$}

2.1 Description of Neutron Flux Trap Plates . . . . . . . . . . 2.7

2.2 Boron Carbide Particle Distribution . . . . . . . . . 2.7

3.1 Measurement Results and Sunmary Description of Experimental Assembly Conditions ................. 3.2

A.1 ASTM Standard B210-78 Specifications for Type 6061 Aluminum . . . A.2

A.2 ASTM Standard B210-78 Specifications for Type 1100 Aluminum . . A A.3

B.1 Analysis of Water Sample .............. B.2

C.1 Trace lmpurities Present in Lattice Plates ......... C.2 


\section{CRITICALITY EXPERIMENTS WITH NEUTRON \\ FLUX TRAPS CONTAINING VOIDS}

\subsection{INTRODUCTION}

A research program was initiated for the U.S. Department of Energy (DOE) by the Sandia National Laboratory Transportation Systems Development Department in 1982 to provide benchmark type experimental criticality data in support of the design and safe operations of nuclear fuel transportation systems. The overall objective of the program is to identify and provide the experimental data needed to form a consistent, firm, and complete data base for verifying calculational models used in the criticality analyses of nuclear transport and related systems.

A report, PNL-6205, issued in June 1988 (Bierman 1988) covered measurement results obtained from a series of experimental assemblies (TTC-1, 2, 3 and 4) involving neutron flux traps. The results obtained on a fifth experimental assembly (TTC-5), modeled after a caiculational problem of The Organization for Economic Cooperation and Development (OECD) Nuclear Energy Agency (NEA) Committee on the Safety of Nuclear Installations (CSNI) Working Group, were presented in, PNL-6838, issued in October 1989 (Bierman 1989). Criticality experiments to measure the reactivity effect of voiding in neutron flux trap regions are covered in this report. As with the previous experiments, the measurements were performed at the U.S. DOE Hanford Critical Mass Laboratory, operated by the Pacific Northwest Laboratory of Battelle Memorial Institute. The work was jointly funded by the DOE Office of Civilian Radioactive Waste Management and the Defense Program.

The measurements were performed in the TTC-3 experimental assembly previously described as arrangement 214R in PNL-6205 (Bierman 1988). Briefly, the experimental assembiy consisted of four water moderated units of 4.31 wt\% $235 \mathrm{U}$ enriched $\mathrm{UO}_{2}$ fuel rods arranged in a $2 \times 2$ array and fully reflected by at least $15 \mathrm{~cm}$ of water. Each fuel unit was near equal in size with the fuel 
uniformly arranged on a $1.891 \mathrm{~cm}$ center-to-center square spacing (1.6 moderator-to-fuel volume ratio). The four fuel units were separated by a $3.73 \mathrm{~cm}$. wide neutron flux trap created by $0.673 \mathrm{~cm}$ thick plates of Boral". The plates contained $0.36 \mathrm{~g} \mathrm{~B} / \mathrm{cm}^{2}$ homogeneously dispersed throughout each plate. Voids were created in the flux trap regions using $0.63 \mathrm{~cm}$ thick type 6061 aluminum plates and $1.27 \mathrm{~cm}$ diameter type 6061 aluminum rods. The critical size of the assembly was determined as voiding was increased from zero in the flux traps to approximately $17 \%, 34 \%$, and $51 \%$. A photograph of the assembiy partially loaded with fuel and no voiding is shown in

Figure 1.1. Details of the measurements and the experimental as sembiy are given in the sections that follow.

m Boral is a trademark product of Brooks and Perkins, Inc. 


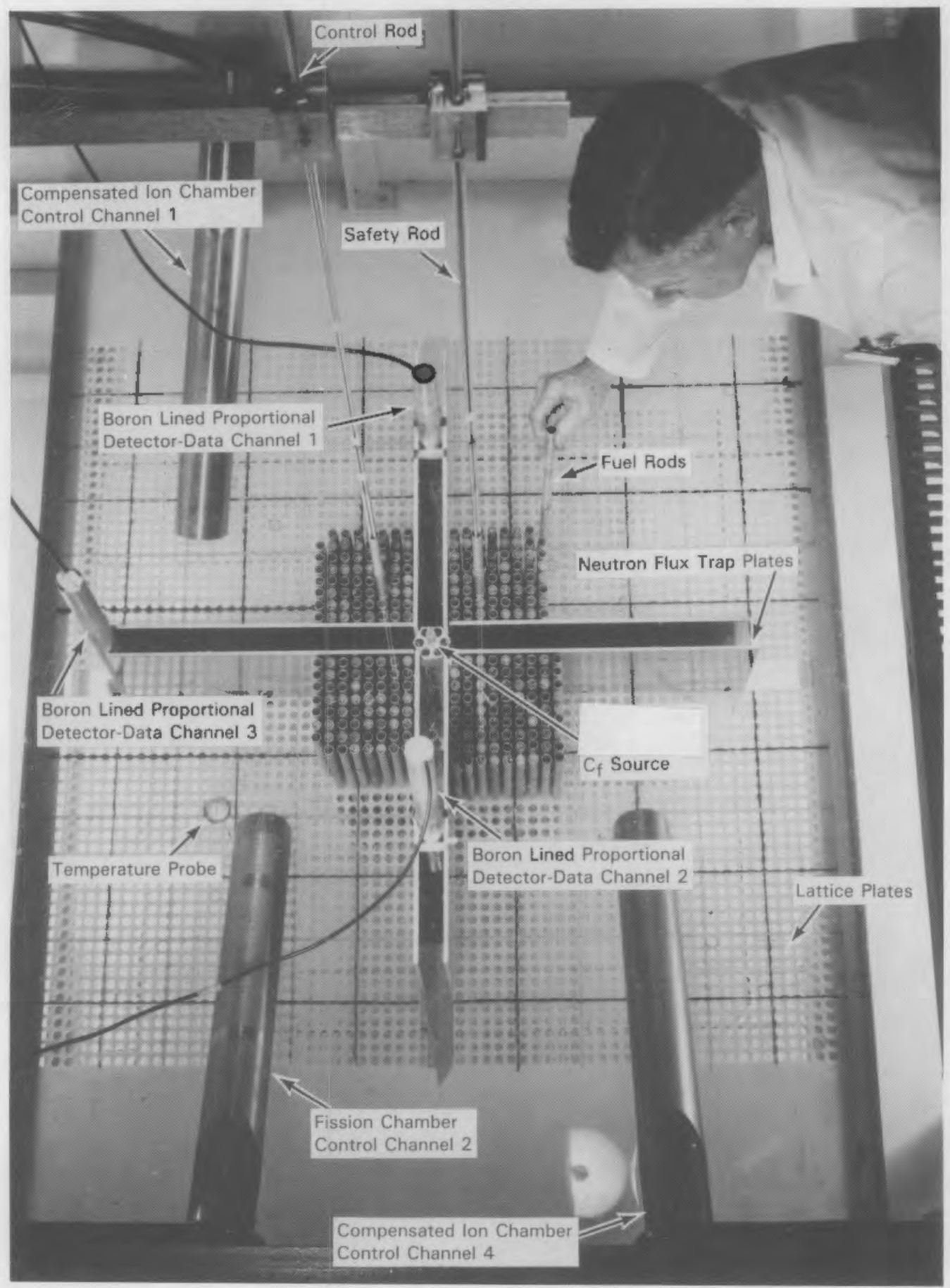

FIGURE 1.1. Photograph of Experimental Assembly Partially Loaded with Fuel 


\subsection{DESCRIPTION OF EXPERIMENTAL ASSEMBLY}

The experimental system and materials associated with the measurements covered by this report are described in this section.

\subsection{GENERAL}

An existing experimental system used previously in fuel element array studies at the Critical Mass Laboratory was used for performing the measurements covered in this report. This system, the Fuel Element Array System (FEAS), consists of a $1.8 \mathrm{~m} \times 3 \mathrm{~m} \times 2.1 \mathrm{~m}$ deep, open-top, carbon-steel tank provided with a moderator/reflector dump valve, a control blade drive, a safety blade drive, a water deionizer, and associated electronic detection and interlock devices. An overall photograph of the system is shown in Figure 2.1.

The control and safety blade drive systems shown in Figure 2.1 were modified to permit replacing the blades with rod-type devices. The experimental assembly shown in Figure 1.1 was positioned in the large tank beneath these drive systems. As shown in Figure 1.1, the experimental assembly consisted of a $2 \times 2$ array of fuel units. The fuel units were separated by $3.73 \mathrm{~cm}$ wide neutron flux trap regions. Each fuel unit was near equal in size and consisted of $4.31 \mathrm{wt} \% 235 \mathrm{U}$ enriched $\mathrm{UO}_{2}$ fuel rods on a square center-to-center spacing of $1.891 \mathrm{~cm}$. This lattice spacing results in a moderator-to-fuel volume ratio of 1.6 , which approximates that typically found in both Boiling Water Reactors (BWR) and Pressurized Water Reactors (PWR). The neutron flux trap regions were created by $0.673 \mathrm{~cm}$ thick plates of Boral containing $0.36 \mathrm{~g} \mathrm{~B} / \mathrm{cm}^{2}$.

The assembly was fully reflected by at least $15 \mathrm{~cm}$ of water on all sides and essentially free of any structural materials in the fuel and flux trap regions. Al1 of the instrument thimbles were located outside the fuel area. Except for the $1.2 \mathrm{~cm}$ diameter type 6061 aluminum guide tubes for the safetycontrol rods and the 0.2 microgram ${ }^{252} \mathrm{Cf}$ source used in the critical approach measurements, all other material (lattice and base support plates) in the fuel-flux trap regions have neutronic properties similar to the water 


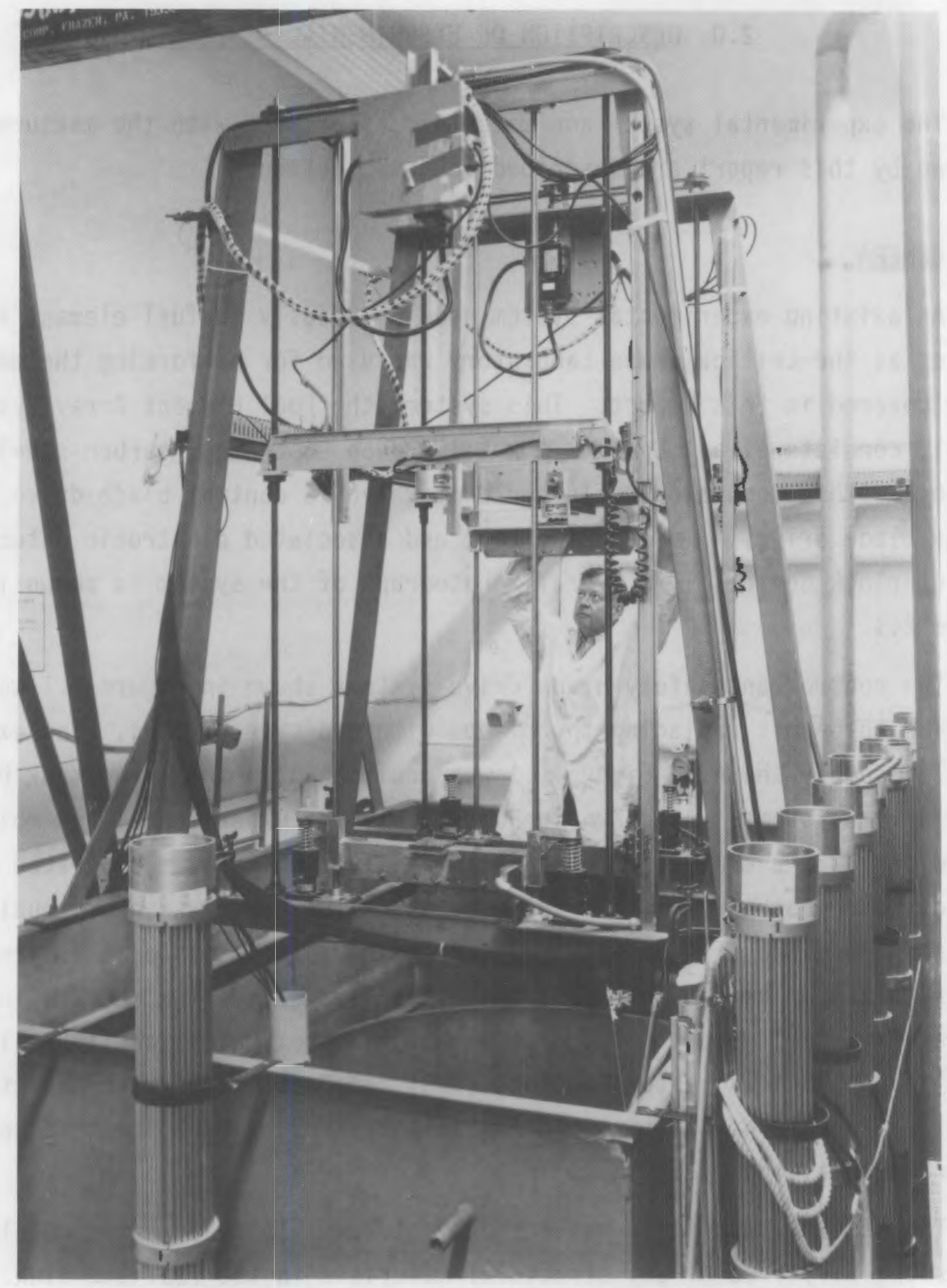

FIGURE 2,1. Experimental System Modified for Use in Experiments 
Fuel: $1.265 \pm 0.003 \mathrm{~cm}$ Dia.

Clad:

Rubber End Cap:

$1.278 \mathrm{~cm} O D \times 2.54 \mathrm{~cm}$ Long

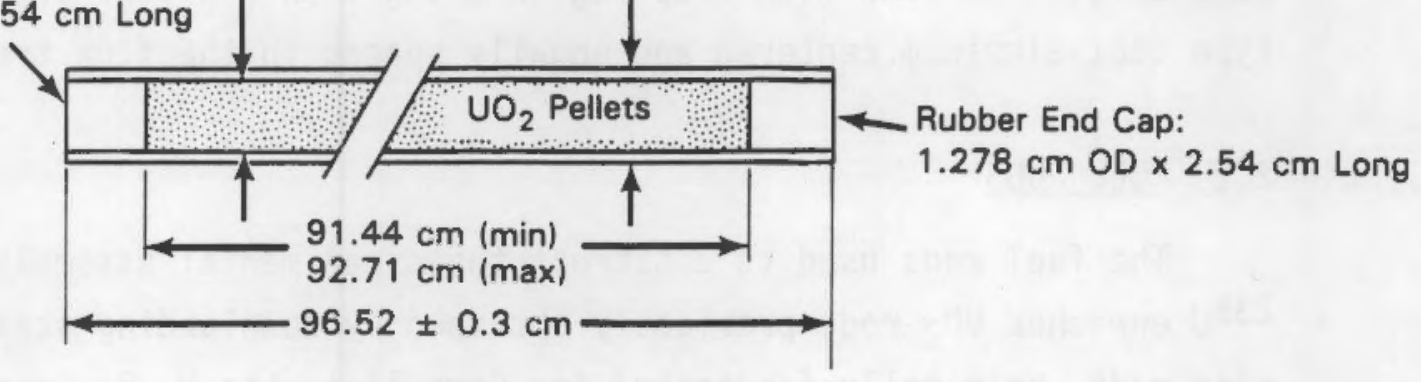

Cladding: 6061 Aluminum Tubing

Loading

Enrichment - $4.306 \pm 0.013 w+\%{ }^{235} \mathrm{U}$

Oxide Density - $10.40 \pm 0.06 \mathrm{~g} / \mathrm{cm}^{3}$

$\mathrm{UO}_{2}-1203.38 \pm 4.12 \mathrm{~g} / \mathrm{Rod}$

$\mathrm{U}-1059.64 \pm 4.80 \mathrm{~g} / \mathrm{Rod}$

Uranium Composition:

$$
\begin{aligned}
& { }^{234} U-0.022 \pm 0.002 w t \% \\
& { }_{225} U-4.306 \pm 0.013 w t \% \\
& { }^{236} U-0.022 \pm 0.002 w t \% \\
& { }^{238} U-95.650 \pm 0.017 w t \%
\end{aligned}
$$

End Cap:

$$
\begin{array}{ll}
\mathrm{C}-58 \pm 1 w t \% & S-1.7 \pm 0.2 \text { wt } \% \\
H-6.5 \pm 0.3 w t \% & 0-22.1 \text { wt } \% \text { (Balance) } \\
\text { Ca-11.4 } \pm 1.8 w t \% & \text { Si- } 0.3 \pm 0.1 \text { wt } \%
\end{array}
$$

Notes:

1. Error limits are one standard deviation

2. End Cap Density is $1.321 \mathrm{~g} / \mathrm{cm}^{3}$

FIGURE 2.2. Description of 4.31 wt\% $235 \mathrm{U}$ Enriched $\mathrm{UO}_{2}$ Fuel Rods 
moderator. Consequently, the assembly can be considered as a fully water reflected and moderated assembly of fuel only, in which the fuel is separated by the flux traps. . Continuous and noncontinuous ("lumped") homogeneous voids were created in each flux trap region using either plates or rods of type 6061 aluminum centered and equally spaced in the flux trays.

\subsection{FUEL RODS}

The fuel rods used to construct the experimental assembly were 4.31 wt\% $235 \mathrm{U}$ enriched $\mathrm{UO}_{2}$ rods previously obtained by downloading stainless steel clad rods, originally fabricated for Core II of the N. S. Savannah (Katz 1969), and reloading the pellets into type 6061 aluminum tubes (see Appendix A for American Society for Testing Materials, T6061 Al specifications). A complete description of these rods is given in Figure 2.2. The uranium assay $(1059.64 \pm 4.80 \mathrm{~g} / \mathrm{rod})$ and the $235 \mathrm{U}$ enrichment $(4.306 \pm 0.013 \%)$ shown in Figure 2.2 for these rods are the average of six assays and six spectrographic analyses made on fuel pellets chosen at random during the reloading. The oxide density $\left(10.40 \pm 0.06 \mathrm{~g} \mathrm{vO}_{2} / \mathrm{cm}^{3}\right)$ given in Figure 2.2 is based on individual volume displacement measurements with 20 pellets selected at random during the reloading operations. The mass of $\mathrm{UO}_{2}$ per rod $(1203.38 \pm$ $4.12 \mathrm{~g}$ ) is the average mass of the 1865 rods of this type available for use in the experiments. The fuel diameter $(1.265 \pm 0.003 \mathrm{~cm})$ given in Figure 2.2 was checked repeatedly during the reloading operations and found to agree with that quoted in the document characterizing Core II of the N. S. Savannah

(Katz 1969). The rubber end cap density $\left(1.321 \mathrm{~g} / \mathrm{cm}^{3}\right)$ quoted in Figure 2.2 for the $4.31 \mathrm{wt} \%{ }^{235} \mathrm{U}$ enriched fuel is the result of a single mass-volume measurement with six end caps selected at random. The composition of the end caps is the result of four analyses on randomly selected end caps.

\subsection{MODERATOR-REFLECTOR}

As indicated previously, the assembly was moderated and fully reflected with water. Impurities analyses of a water sample taken during the experiments are given in Appendix B. 


\subsection{LATTICE PLATES AND SUPPORTS}

Three $1.23 \pm 0.01 \mathrm{~cm}$ thick, polypropylene lattice plates, having a $\mathrm{C}_{3} \mathrm{H}_{6}$ molecular structure and a density of $0.90 \mathrm{~g} / \mathrm{cm}^{3}$, were used to achieve and maintain uniform spacings between the fuel pins in the experimental assembly and between the fuel and the flux traps. Trace impurity levels for the lattice plates are given in Appendix C. These plates, which have neutronic properties similar to the water moderator, were the only structural materials in the fuel-moderator region of each assembly. The elevation of each lattice plate relative to other components in the experimental assembly is shown in Figure 2.3.

The fuel rods were supported on a $5.08 \mathrm{~cm}$ thick acrylic plate $\left(1.185 \mathrm{~g} / \mathrm{cm}^{3}\right.$ containing $8 \mathrm{wt} \% \mathrm{H}, 60 \mathrm{wt} \% \mathrm{C}$ and $32 \mathrm{wt} \% 0$ ) mounted off the FEAS tank walls. The elevation of the acrylic support plate, relative to components in the experimental assembly is shown in Figure 2.3.

\subsection{FLUX TRAP PLATES}

The neutron flux traps between the fuel units were created by positioning parallel plates of Boral ${ }^{\mathrm{m}}$, separated by $3.73 \pm 0.02 \mathrm{~cm}$ of water, between the fuel. The fuel units were not encased on all four sides since the measurements are concerned only with interaction between the units. Also, not encasing the fuel on all sides permitted varying the size of the fuel units as voiding in the flux traps varied.

The Boral plates consisted of a homogeneous matrix of aluminum and boron carbide particles sandwiched between two thin $(0.102 \mathrm{~cm})$ sheets of type $1100 \mathrm{Al}$. The boron loading was $0.36 \pm 0.02 \mathrm{~g} \mathrm{~B} / \mathrm{cm}^{2}$. The composition and the physical description of these plates are given in Table 2.1.

m Boral is a trademark of Brooks and Perkins, Inc. 


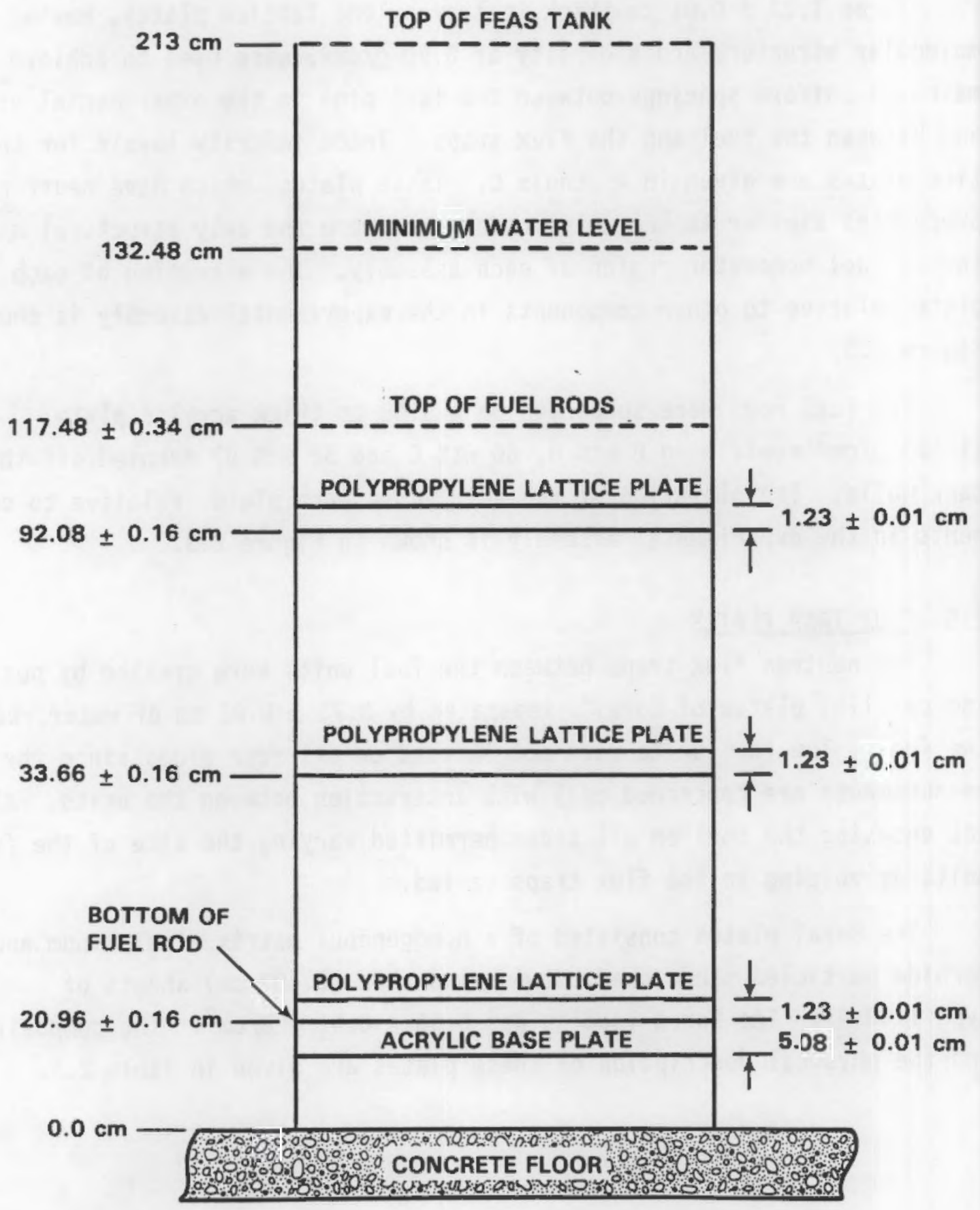

FIGURE 2.3. Experimental Assembly Elevations 
TABLE 2.1. Description of Neutron Flux Trap Plates

Element, wt\%

A)

B

C

0

$\mathrm{Fe}$

Core Density, $\mathrm{g} / \mathrm{cm}^{3}$

Core Thickness, $\mathrm{cm}$

Length, cm

Width, $\mathrm{cm}$ $w t \%$

$\begin{array}{rr}62.54 & \pm 2.43 \\ 29.22 & \pm 1.87 \\ 8.16 & \pm 0.52 \\ 0.06 & \\ 0.02 & \end{array}$

$2 / 64 \pm 0.01$

$0.470 \pm 0.003$

96

45

The boron carbide particle size distribution is given in Table 2.2 and American Society for Testing Materials (ASTM) specifications for type 1100 aluminum are given in Appendix A.

\section{IABLE 2.2 Boron Carbide Particle Distribution}

\begin{tabular}{|c|c|}
\hline $\begin{array}{c}\text { Particle Diameter, } \\
\mathrm{cm}\end{array}$ & $\begin{array}{c}\text { Distribution, } \\
\text { wt\% }\end{array}$ \\
\hline$>0.0300$ & 0 \\
\hline$>0.0180$ & 8.6 \\
\hline$>0.0045$ & 81.7 \\
\hline$<0.0045$ & 9.7 \\
\hline
\end{tabular}

\subsection{VOIDING MATERIALS}

Continuous homogeneous voidings of $16.89 \pm 0.07 \%, 33.78 \pm 0.10 \%$ and $50.67 \pm 0.12 \%$ were created in the neutron flux traps by using $0.630 \pm 0.005 \mathrm{~cm}$ thick plates of type 6061 aluminum plates equally spaced, and centered, in each flux trap region. To obtain comparable data, $1.27 \pm 0.005 \mathrm{~cm}$ diameter type 6061 aluminum rods, centered in each flux trap region on $1.891 \pm \mathrm{cm}$ center-to-center spacings, were used to create a noncontinuous homogeneous voiding of $17.96 \pm 0.09 \%$. ASTM specifications for the type 6061 aluminum are given in Appendix A. 


\subsection{CONTROL AND SAFETY BLADES}

The FEAS control and safety drives were provided with gadol inium rods such that each experimental assembly could be constructed in compliance with operating regulations and procedures. These rods and their associated type 6061 aluminum guides were located in the fuel regions of the experimental assembly such that the rods fall by gravity into the assembly should an out-of-range condition exist in the control channels shown in Figure 1.1. The control and safety rods are not defined since all of the data reported herein were obtained with these rods fully withdrawn from the experimental assembly. ASTM specifications for the aluminum sleeves are given in Appen$\operatorname{dix} A$. The aluminum sleeves extended from the acrylic base plate shown in Figure 2.3 to above the top reflector level at locations shown in the loading diagrams for each assembly arrangement. The sleeves had a $1.283 \mathrm{~cm}$ inside diameter and a wall thickness of $0.066 \mathrm{~cm}$. 


\subsection{EXPERIMENTAL MEASUREMENTS AND RESULTS}

Since the objective of the experiments is to determine the reactivity effects caused by voids being introduced in neutron flux traps, the measurements were performed in an experimental assembly previously used to obtain data on the reactivity effectiveness of neutron flux traps created by parallel Boral plates positioned between fuel units. The results of these previous experiments demonstrated that the effectiveness of neutron flux traps for criticality control was essentially insensitive to boron loadings above about $0.1 \mathrm{~g} \mathrm{~B} / \mathrm{cm}^{2}$ (Bierman 1988). To assure that the results obtained on the reactivity effects of voiding were relatively insensitive to errors in the boron loading, the TTC-3 assembly containing neutron flux trap regions created with plates having a boron loading of $0.36 \mathrm{~g} \mathrm{~B} / \mathrm{cm}^{2}$ was chosen as the reference assembly with zero voiding. A loading diagram for the reference TTC-3 assembly, which was a $2 \times 2$ array of fuel and is identified as $214 R$, is given in Appendix D.

Continuous homogeneous voids of $16.89 \pm 0.07 \%, 33.78 \pm 0.10 \%$ and $50.67 \pm 12 \%$ were created in the $214 \mathrm{R}$ assembly flux trap regions by centering 1,2 and 3 type 6061 aluminum plates, respectively, in the flux traps. As indicated in Section 2.6, the plates were of equal thickness and positioned such that 1,2 and 3 equally spaced void regions were created in the flux trap. For each of these voiding conditions, the critical size of the assembly was determined. The results obtained are given in Table 3.1. The fractional changes observed in the critical size as voiding was increased in the experimental assembly are shown in Figure 3.1. Fuel loading and assembly diagrams are given in Appendix $D$ for each voiding condition. To the extent permitted by the delayed critical condition, fuel was distributed equally between the four fuel units for each assembly condition.

The critical size for each condition identified in Table 3.1 was determined by the approach-to-critical method to obtain well-defined, fully waterreflected, neutron flux trap assemblies consisting of water moderated fuel only. In an approach-to-critical measurement to determine the critical conditions for a system, neutron multiplication measurements are made as the parameter of interest is varied such that the system "approaches" 
TABLE 3.1. Measurement Results and Summary Description of Experimental Assembly Conditions

\begin{tabular}{|c|c|c|c|c|}
\hline \multirow{2}{*}{\multicolumn{2}{|c|}{$\frac{\begin{array}{c}\text { Experiment } \\
\text { Number }\end{array}}{214 \mathrm{R}}$}} & $\begin{array}{l}\text { Voiding Material } \\
\text { in Each Flux Trap } \\
\text { (a) }\end{array}$ & $\begin{array}{l}\text { Voiding in } \\
\text { Each Flux Trap } \\
\text { (volume \%) } \\
\end{array}$ & $\begin{array}{c}\text { Assembly Loading (b) } \\
\text { for Delayed Criticality } \\
\text { (fuel rods) }\end{array}$ \\
\hline & & None & 0 & $952 \pm 2$ \\
\hline \multirow{11}{*}{$\begin{array}{l}\omega \\
\omega\end{array}$} & 214 V1 & One Aluminum Plate & $16.89 \pm 0.07$ & $924.6 \pm 1.9$ \\
\hline & 214 V2 & Two Aluminum Plates & $33.78 \pm 0.10$ & $896.2 \pm 2.2$ \\
\hline & 214 V3 & Three Aluminum Plates & $50.67 \pm 0.12$ & $862.1 \pm 1.2$ \\
\hline & 214 V4 & 12 Aluminum Rods & - & $925.4 \pm 1.3$ \\
\hline & 214 V5 & 14 Aluminum Rods & - & $924.9 \pm 1.6$ \\
\hline & (c) & 15 Aluminum Rods & $17.96 \pm 0.09$ & 924.7 (c) \\
\hline & 214 F1 & 11 Fuel Rods & - & $873.7 \pm 1.0(d)$ \\
\hline & 214 F2 & 12 Fuel Rods & - & $866.9 \pm 0.3(d)$ \\
\hline & 214 F3 & 14 Fuel Rods & - & $858.5 \pm 0.1$ (d) \\
\hline & (d) & 15 Fuel Rods & $22.30 \pm 0.11(\mathrm{e})$ & 856 (d) \\
\hline & \multicolumn{4}{|c|}{$\begin{array}{l}\text { (a) Refer to loading diagrams in appendix for location of voiding material in each flux trap } \\
\text { (b) Error limits are one standard deviation estimates } \\
\text { (c) Linear extrapolation of } 214 \text { V4 and } 214 \text { V5 results } \\
\text { (d) Linear extrapolation of } 214 \mathrm{~F} 1,214 \mathrm{~F} 2 \text { and } 214 \mathrm{~F} 3 \text { results, critical loading does not include } \\
\text { fuel rods in flux trap regions } \\
\text { (e) Moderator displacement }\end{array}$} \\
\hline
\end{tabular}




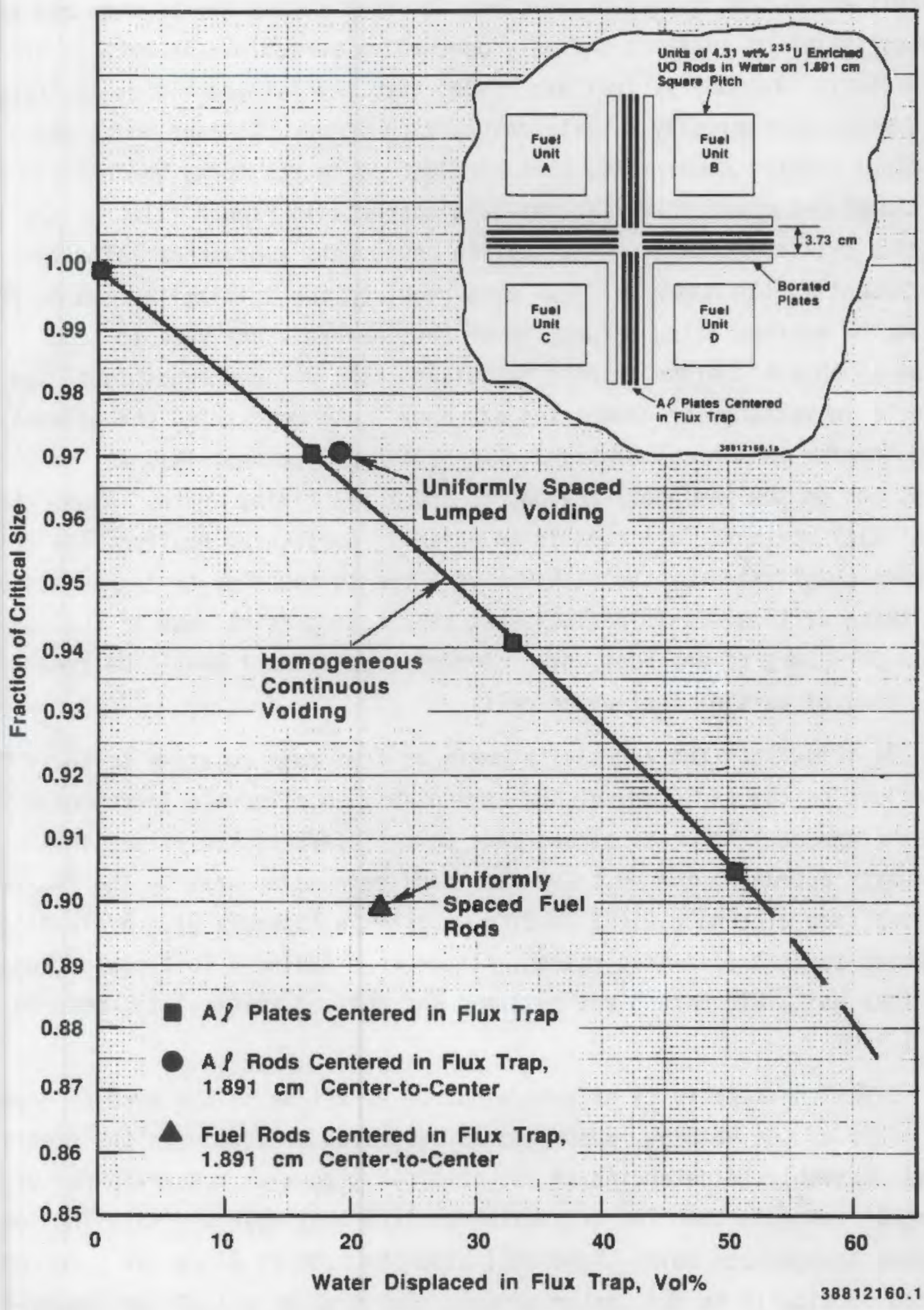

FIGURE 3.1. Variation in Critical Size with Flux Trap Voiding 
criticality. By extrapolating subcritical data very near critical, a precise definition of the critical conditions for that system can be obtained with the parameter of interest the only perturbing variable. In each of the experimental assemblies fuel was loaded into the lattice plates in increments that were neutronically symmetrical to each other. At each incremental fuel loading, neutron count rates were obtained using the three boron-lined proportional detectors identified as data channels in Figure 1.1. At the delayed critical condition the neutron count rate approaches infinity. Consequently, the number of fuel pins required for criticality can be predicted by extrapolating a function of the inverse count rate to zero. Although this technique results in "clean" well-defined conditions, the results in rectangular geometries can complicate describing the assembly geometry for use in calculations. In rectangular geometries, all fuel rod locations on the periphery are not of equal reactivity worth. Also, the reactivity worth of fuel rods in an assembly containing neutron flux traps is further complicated by the nearness of a rod to the flux trap. Consequently, for those critical fuel loadings that result in partial rows of fuel in the outer periphery of any fuel unit, partial rows of fuel should be treated as full rows of partial fuel-water cells.

To illustrate the reactivity worth of fuel rods relative to their locations on the periphery of the assemblies, an alternate incremental loading approach to critical was made on the 214V3 assembly. In this alternate approach, the last few fuel rods were added next to the flux trap regions (see alternate 214V3 loading diagram in Appendix $D$ ). By loading adjacent to each flux trap region, rather than adding a full row of rods to one fuel unit, 876.6 rods are required for delayed criticality compared to 862.1 .

Since the reactivity effects might be sensitive to the form or geometrical shape of the voiding, measurements were also performed in the experimental assembly to determine if the critical size with noncontinuous or "lumped" voids in the flux trap differed from that observed with the continuous homogeneous void. Type 6061 aluminum rods $(1.27 \mathrm{~cm}$ dia $\times 96 \mathrm{~cm})$ were spaced vertically in the center of each flux trap on a $1.891 \mathrm{~cm}$ center-tocenter spacing to obtain "lumped" voiding of $17.96 \pm 0.09 \%$ in the critical 
assembly. The results of these measurements are given in Table 3.1 and compared with the continuous voiding results in Figure 3.1. As can be seen in Figure 3.1, the uniformly spaced aluminum rods resulted in a slight decrease in reactivity equivalent to about $0.4 \%$ in critical size.

In addition to providing data on the lumping effect of voids in flux traps, the measurements with aluminum rods also provided an opportunity to obtain data on the effect that fuel rods in these regions would have on the reactivity of the assembly. The results of these measurements with the aluminum rods replaced with fuel rods are given in Table 3.1 and compared with the continuous and lumped voiding results in Figure 3.1. Although the reactivity effect is dependent on the number of fuel rods in the flux trap regions, the measurement data indicate a maximum is approached as the number of rods in a region approaches the number in the adjacent array face. This maximum value for the experimental assembly is shown in Figure 3.1. As can be seen, fuel in the flux trap regions has a significant effect $(\sim 10 \%)$ on the assembly size. Figure 3.2 is a photograph of the assembly with the fuel rods in the flux trap regions. 


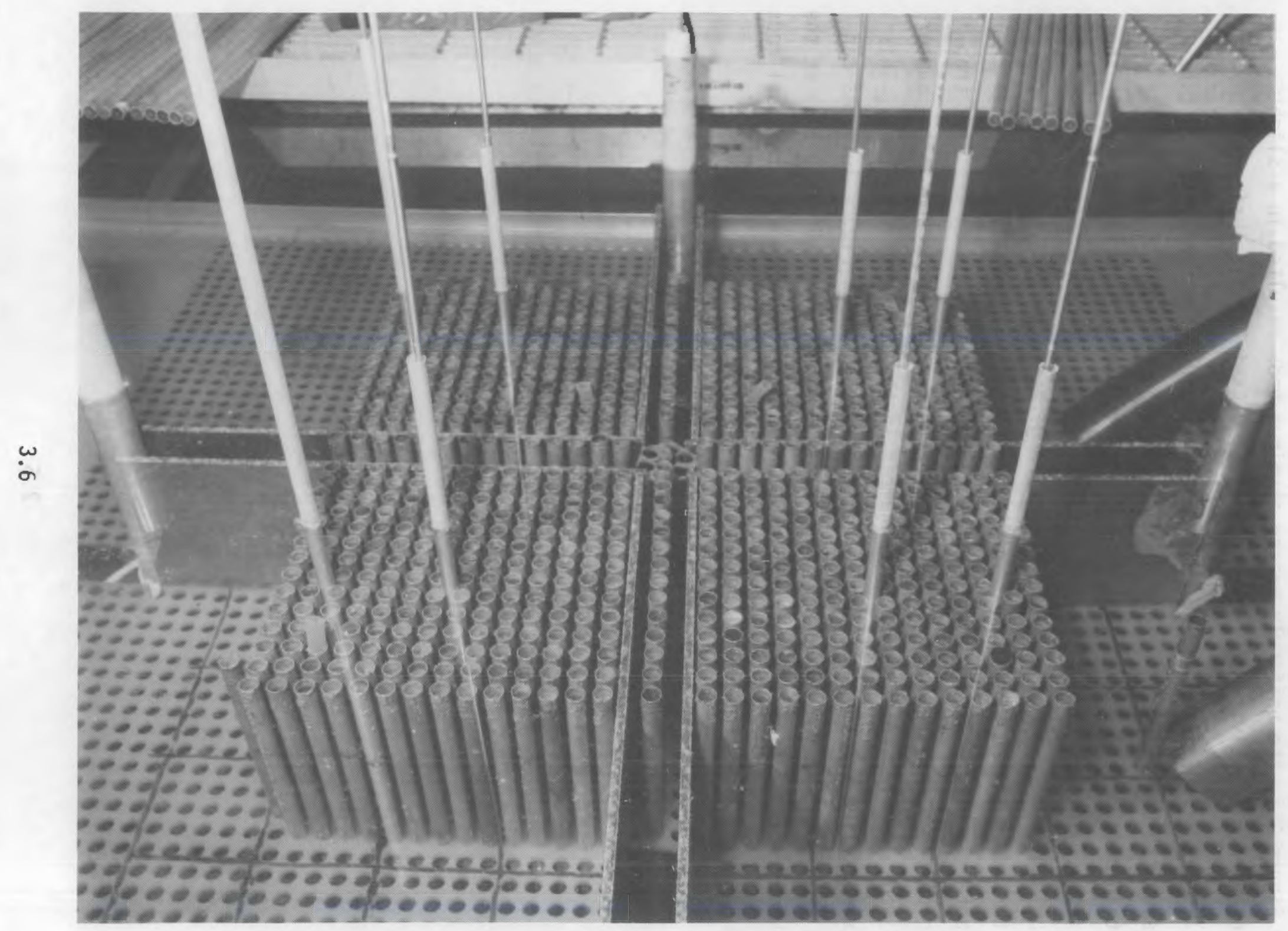

FIGURE 3.2. Photograph of TTC-3 Assembly with Fuel Rods in the Flux Traps 


\subsection{SUMMARY OF RESULTS}

The introduction of up to $51 \%$ voiding in the neutron flux trap regions decreased the critical size of the experimental assembly by about $9.5 \%$. The geometry or location of the voids in the flux trap regions appeared to have little effect on the reactivity of the system. It should be noted, however, that this observation may be dependent on the width of the flux trap.

The presence of fuel rods in the flux trap regions increases the reactivity significantly. With fuel rods equally spaced over the length and in the center of the flux trap regions, a decrease of about $10 \%$ was observed in the critical size of the experimental assembly. 


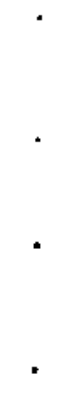

- 


\subsection{ACKNOWLEDGMENTS}

The cooperation and assistance of Critical Assembly Operators J. H. Smith and M. A. Covert in performing the experiments is gratefully acknow]edged and appreciated. Also appreciated is the review of this report by E. D. Clayton of PNL (Ret.) and G. R. Smolen of the Oak Ridge National Laboratory. 


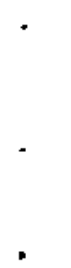

. 


\subsection{REFERENCES}

Bierman, S. R. 1988. "Criticality Experiments to Provide Benchmark Data on Neutron Flux Traps." PNL-6205, Pacific Northwest Laboratory, Richland, Washington.

Bierman, S. R 1989. "Reactivity Measurements on an Experimental Assembly of 4.31 WT\% $235 \mathrm{~V}$ Enriched $00_{2}$ Fue 1 Rods Arranged in a Shipping Cask Geometry." PNL-6838/TTC-0895, Pacific Northwest Laboratory, Richland, Washington. 


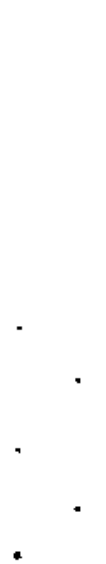




\section{APPENDIX A}

DENSITY AND CHEMICAL COMPOSITION OF TYPE 6061 AND TYPE 1100 ALUMINUM 
APPENDIX A

DENSITY AND CHEMICAL COMPOSITION OF TYPE 6061 AND TYPE 1100 ALUMINUM

Density and American Society for Testing Materials (ASTM) chemical specifications for the aluminum present in the experimental assemblies are presented in this appendix.

A.1 
TABLE A.1. ASTM Standard B210-78 Specifications for TYPE 6061 Aluminum

\title{
Chemical Composition
}

Element

Si

$\mathrm{Fe}$

$\mathrm{Cu}$

$\mathrm{Mn}$

$\mathrm{Mg}$

Cr

Zn

$\mathrm{Ti}$

A1
Wt\%

$0.40-0.80$

0.7 (Maximum)

$0.15-0.40$

0.15 (Maximum)

$0.8-1.2$

$0.04-0.35$

0.25 (Maximum)

0.15 (Maximum)

Remainder

$97.36 \rightarrow 96.15$

\section{Maximum Impurities}

Element

Each

Total
$\mathrm{Wt} \%$

0.05

0.15

\author{
Density: $2.69 \mathrm{~g} / \mathrm{cm}^{3}$ \\ (not part of standard - measured by volume displacement)
}


TABLE A.2. ASTM Standard B210-78 Specifications for TYPE 1100 Al uminum

\section{Chemical Composition}

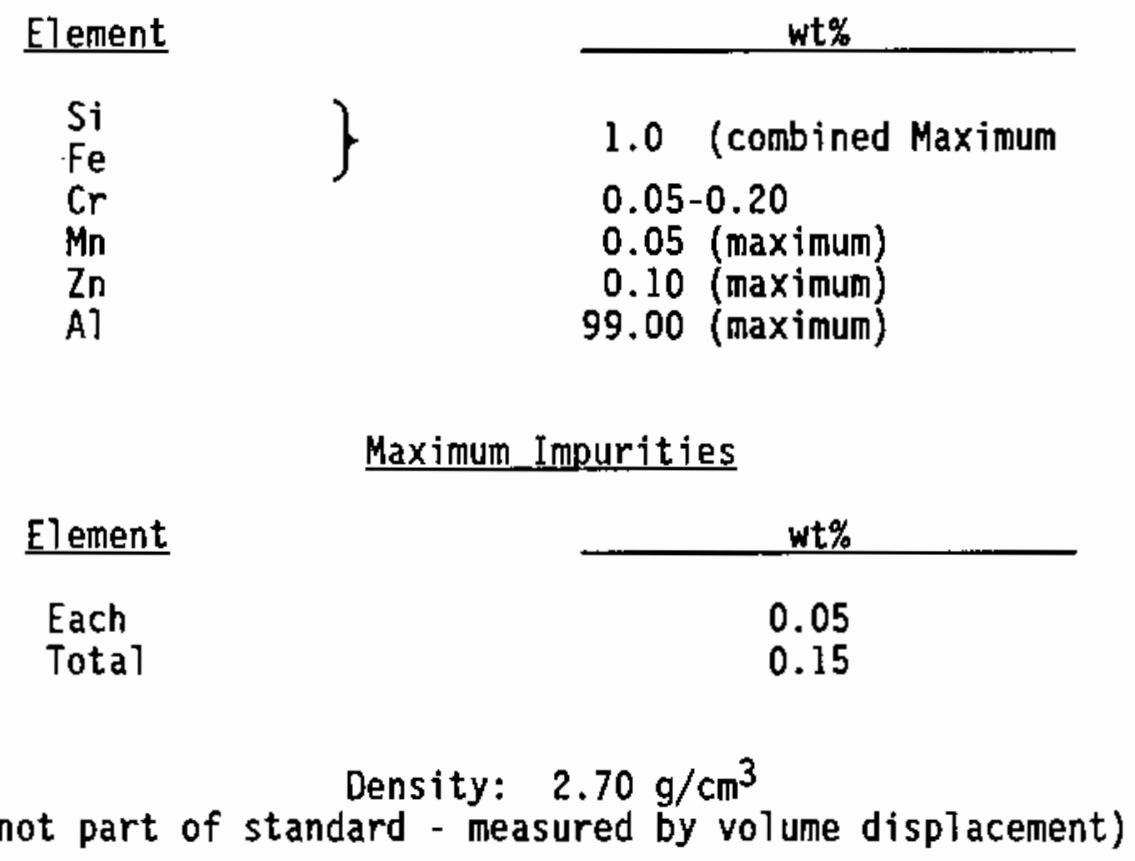

A.3 


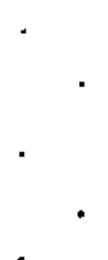

, 


\section{APPENDIX B}

TRACE IMPURITIES PRESENT IN THE WATER

MODERATOR-REFLECTOR OF THE EXPERIMENTAL ASSEMBLY 


\section{APPENDIX B}

TRACE IMPURITIES PRESENT IN THE WATER MODERATOR-REFLECTOR OF THE EXPERIMENTAL ASSEMBLY

Samples were taken during the experiments of the water moderatorreflector. The results of the sample analyses are presented in this appendix. A11 analyses were performed in accordance with Standard Methods for the Examination of Water and Waste Water, 15th ed., American Public Health Association, Washington, $D C$. 
IABLE B.1. Analysis of Water Sample

Analysis

$\mathrm{pH}$

Total alkalinity $\mathrm{mg} / \mathrm{liter}$ as $\mathrm{CaCO}_{3}$

Bicarbonate Alkalinity $\mathrm{mg} / \mathrm{liter}$ as $\mathrm{CaCO}_{3}$

Carbonate alkalinity $\mathrm{mg} / 1$ iter as $\mathrm{CaCO}_{3}$

Total dissolved solids $\mathrm{mg} / \mathrm{liter}$

Sulfate $\mathrm{mg} / \mathrm{liter}$

Nitrate (as $\mathrm{N}$ ) $\mathrm{mg} / \mathrm{Titer}$

Fluoride $\mathrm{mg} / \mathrm{liter}$

Chloride $\mathrm{mg} / \mathrm{liter}$

Cadmium mg/liter

Copper $\mathrm{mg} / 1$ iter

Chromium $\mathrm{mg} / \mathrm{l}$ iter

Iron $\mathrm{mg} / 1$ iter

Lead $\mathrm{mg} / \mathrm{liter}$

Manganese $\mathrm{mg} / \mathrm{liter}$

Zinc $\mathrm{mg} / \mathrm{liter}$

Boron $\mathrm{mg} / \mathrm{liter}$

Gadolinium $\mathrm{mg} / \mathrm{liter}$
Sample Number

TTC 214F1

7.5

35

33

$<0.5$

83

16

2.83

0.12

18

0.0006

$<0.05$

$<0.005$

0.20

$<0.005$

$<0.01$

0.32

$<25$

$<10$ 


\section{APPENDIX C}

IMPURITIES MEASURED IN LATTICE PLATE MATERIAL 


\section{APPENDIX C}

\section{TRACE IMPURITIES MEASURED IN LATTICE PLATE MATERIAL}

Trace impurity levels are presented in this appendix for the polypropylene material used in fabricating the lattice plates for these experiments. The analytical results are from a spark source mass spectrographic analysis of samples taken from, and considered representative of, the polypropylene lattice plates. The spectrographic analysis were performed by the Hanford Engineering Development Laboratory, Richland, Washington, on October 17, 1985. 
IABLE C.1. Trace Impurities Present in Lattice Plates (parts per million by weight)

\begin{tabular}{|c|c|}
\hline Element & $\begin{array}{l}\text { Sample Number } \\
\text { TTC }-4 \\
\end{array}$ \\
\hline $\mathrm{Lj}$ & 0.2 \\
\hline $\mathrm{Be}$ & 1 \\
\hline B & 0.04 \\
\hline$F$ & - \\
\hline $\mathrm{Na}$ & $<10$ \\
\hline $\mathrm{Mg}$ & $<6$ \\
\hline A1 & 30 \\
\hline $\mathrm{Si}$ & 8 \\
\hline $\mathrm{P}$ & 5 \\
\hline $\mathrm{Cl}$ & 1 \\
\hline K & 40 \\
\hline $\mathrm{Ca}$ & - \\
\hline $\mathrm{Ti}$ & $<100$ \\
\hline$V$ & 3 \\
\hline $\mathrm{Cr}$ & $<10$ \\
\hline Mn & $<2$ \\
\hline $\mathrm{Fe}$ & -- \\
\hline $\mathrm{Cu}$. & 100 \\
\hline $2 n$ & $<10$ \\
\hline $\mathrm{Ge}$ & $\cdots$ \\
\hline As & $<5$ \\
\hline $\mathrm{Rb}$ & - \\
\hline Y & - \\
\hline $\mathrm{Zr}$ & $\cdots$ \\
\hline Mo & -- \\
\hline Sn & -- \\
\hline $\mathrm{Br}$ & - \\
\hline
\end{tabular}

C.2 
APPENDIX D

LOADING DIAGRAMS OF THE EXPERIMENTAL ASSEMBLIES 


\section{LOADING DIAGRAMS OF THE EXPERIMENTAL ASSEMBLIES}

Diagram plans of the fuel-moderator region of each experimental assembly arrangement are presented in this appendix. The final subcritical fuel loading arrangement is shown and the total number of fuel rods predicted for delayed criticality is given for each assembly. Final fuel loadings for all of the assemblies are within about $1 \%$ of the delayed critical loading except for assembly $214 \mathrm{Fl}$. Assembly $214 \mathrm{Fl}$ was within $2.2 \%$ of the delayed critical loading. The temperature of the moderator and reflector regions was essential constant over the experiments at $18 \mathrm{C} \pm 2 \mathrm{C}$. 


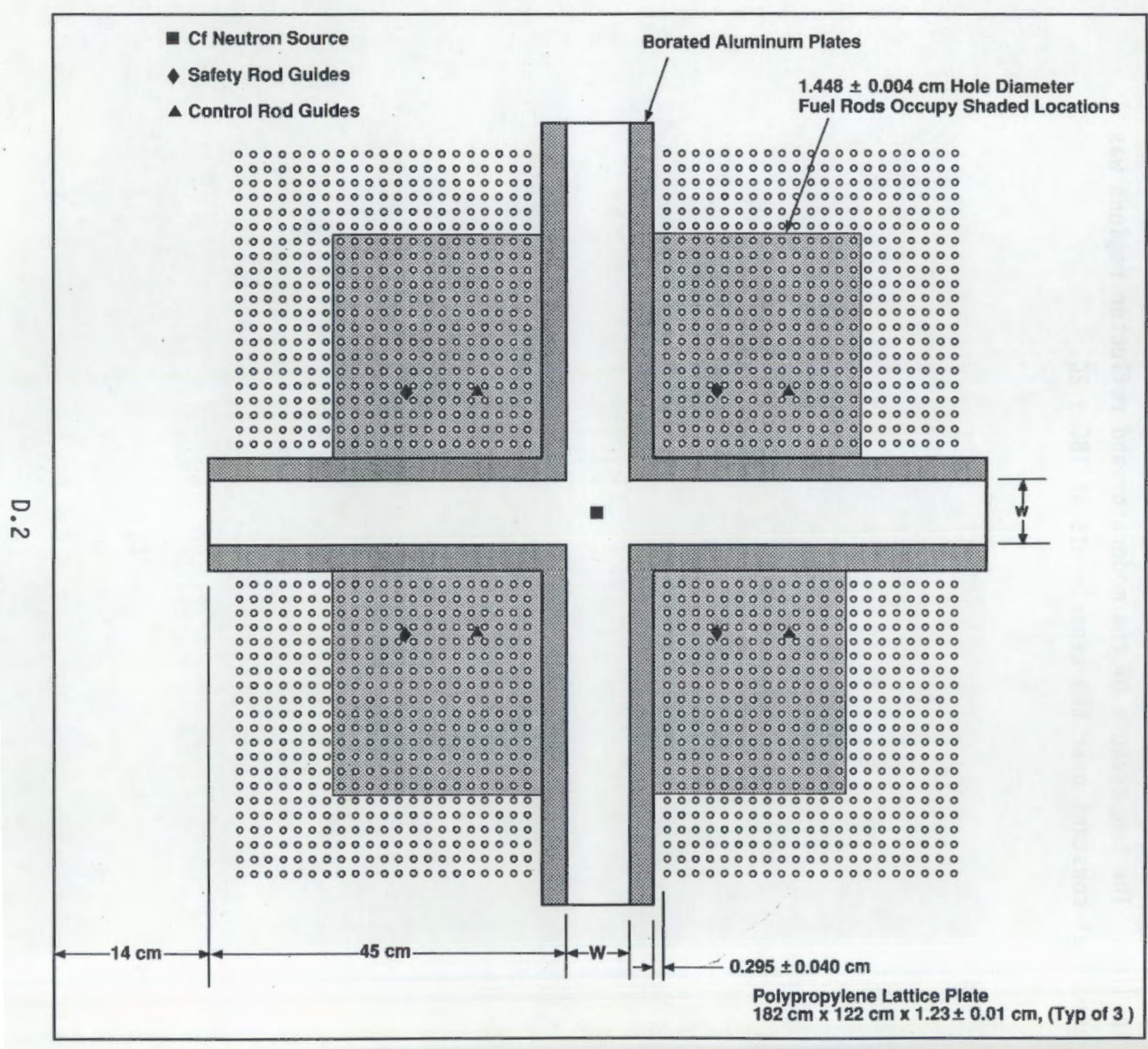

$\begin{array}{ll}\text { Assembly Number } & : 214 \mathrm{R} \\ \text { Lattice Pitch } & : 1.891 \pm 0.001 \mathrm{~cm} \\ \text { Safety Rods } & : \text { Out of System } \\ \text { Control Rods } & : \text { Out of System } \\ \text { Fuel Rods } & : 945 \text { (see comments) } \\ \text { Fuel } & : 4.31 \text { wt\% } 235 \mathrm{U} \text { Enriched } \mathrm{UO}_{2} \\ \text { Flux Trap Width, W } & : 3.73 \pm 0.02 \mathrm{~cm} \\ \text { Plates } & \vdots \text { Boral } \\ \text { Boron } & \vdots 0.36 \pm 0.02 \mathrm{gB} / \mathrm{cm}^{2} \\ \text { Voiding Material } & : \text { None } \\ \text { Comments } & : 952 \text { Rods Predicted for } \\ & \text { Delayed Criticality }\end{array}$

Polypropylene Lattice Plate

$182 \mathrm{~cm} \mathrm{x} 122 \mathrm{~cm} \times 1.23 \pm 0.01 \mathrm{~cm}$, (Typ of 3 ) 


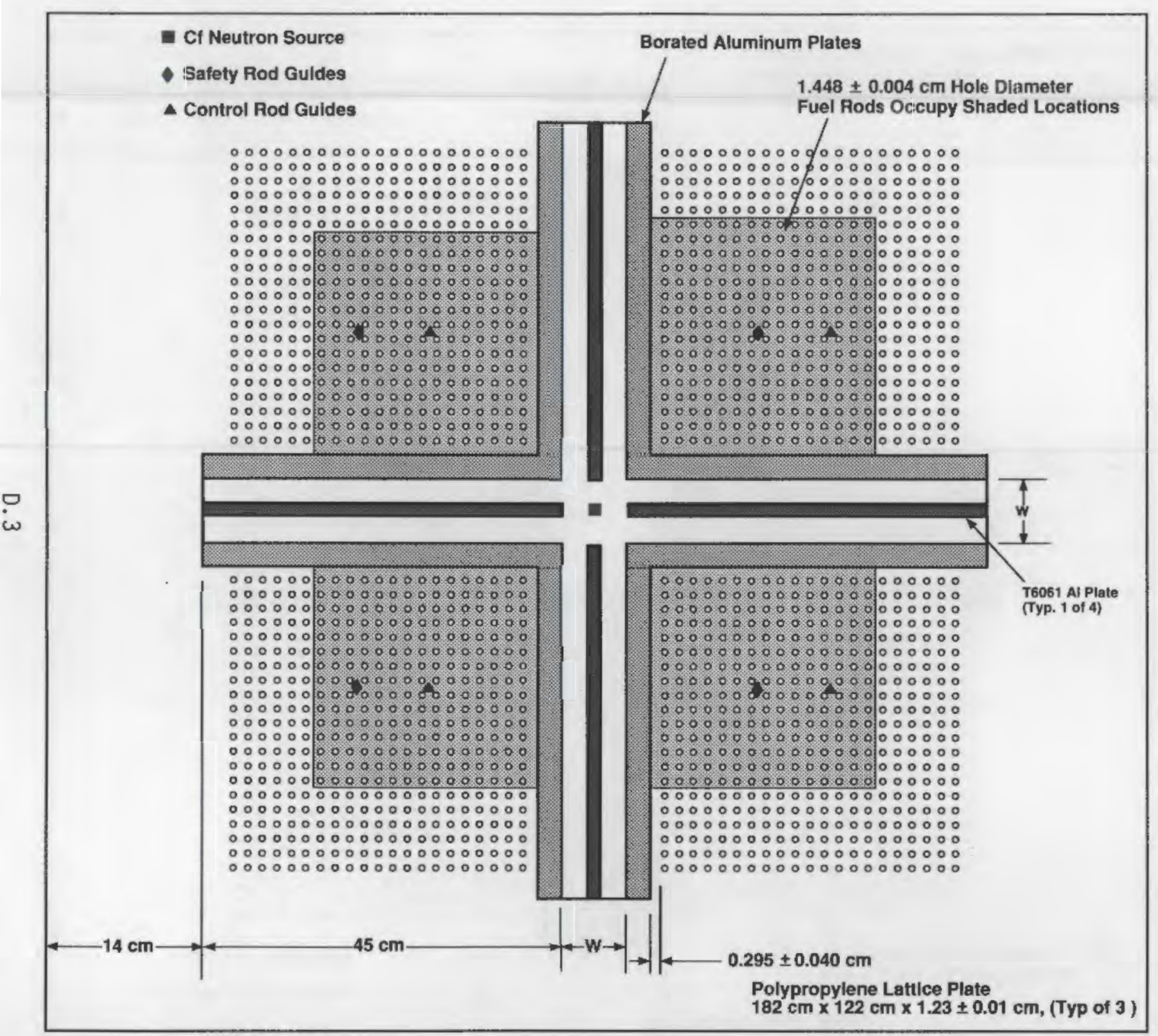

Assembly Number Lattlce Pltch Control Rods

Fuel Rods

Fuel

Flux Trap Width, w

Plates

Voiding Materia

Comments
: 214V1

$: 1.891 \pm 0.001 \mathrm{~cm}$

Out of System Out of System

: 915 (see comments) : 4.31 wt\% ${ }^{235} \mathrm{U}$ Enriched UO $3.73 \pm 0.02 \mathrm{~cm}$ $0.36 \pm 0.02 \mathrm{gB} / \mathrm{cm}^{2}$

$0.63 \pm 0.001 \mathrm{~cm}$ tk Al Plate 924.6 \pm 1.9 Rods Predicted for Delayed Critlcality 


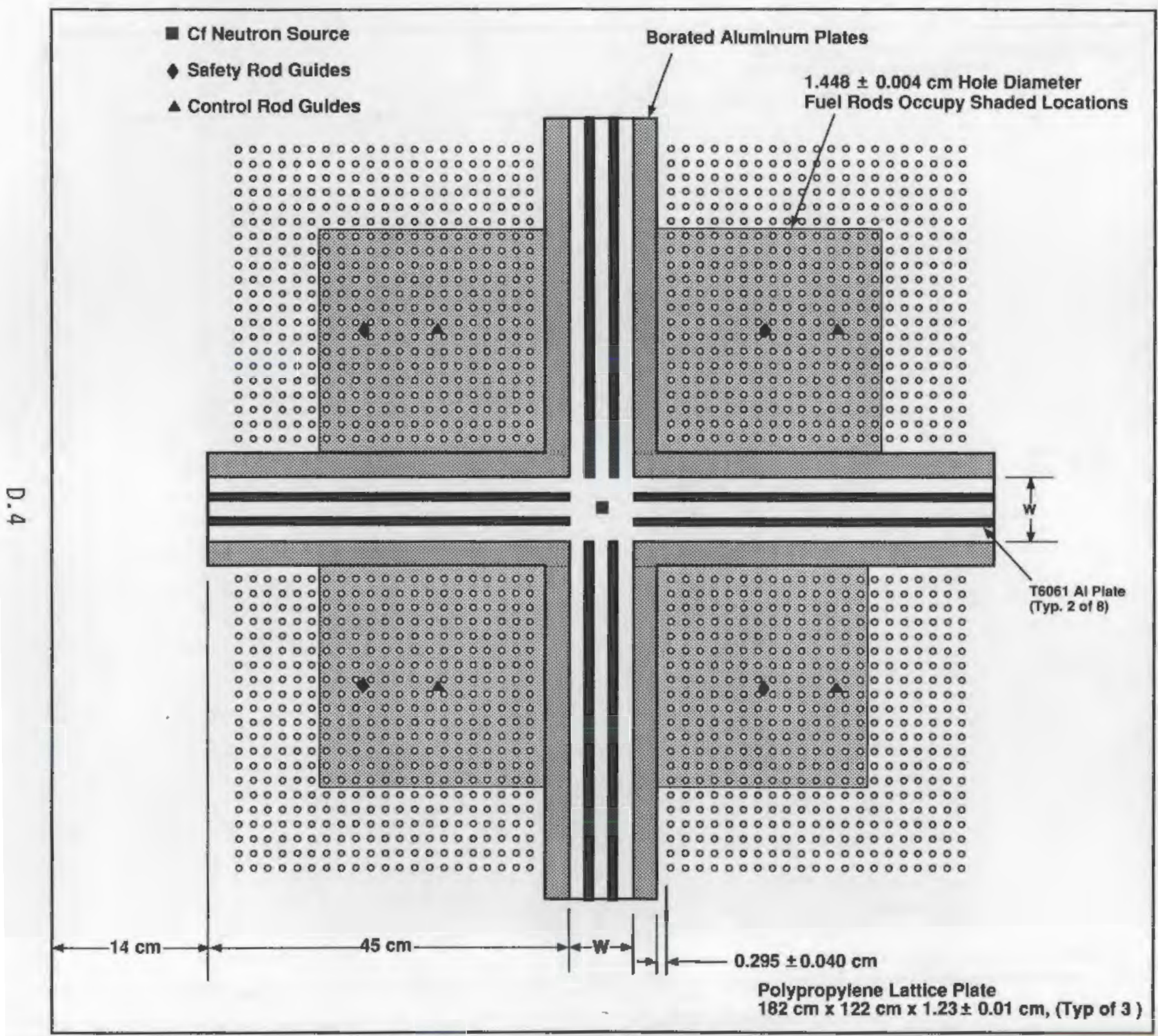

Assembly Number :214V2

Lattlce Pltch $\quad: 1.891 \pm 0.001 \mathrm{~cm}$

Safety Rods : Out of System

Control Rods : Out of System

Fuel Rods : 885 (see comments)

Fuel $\quad: 4.31$ wt\% ${ }^{235} \mathrm{U}$ Enriched $\mathrm{UO}_{2}$

Flux Trap Width, $W: 3.73 \pm 0.02 \mathrm{~cm}$

Plates

Voiding Material : Boral

Comments

Al Plate

896.2+ 2.2 Rods Predicted for Delayed Criticality

Polypropylene Lattice Plate 


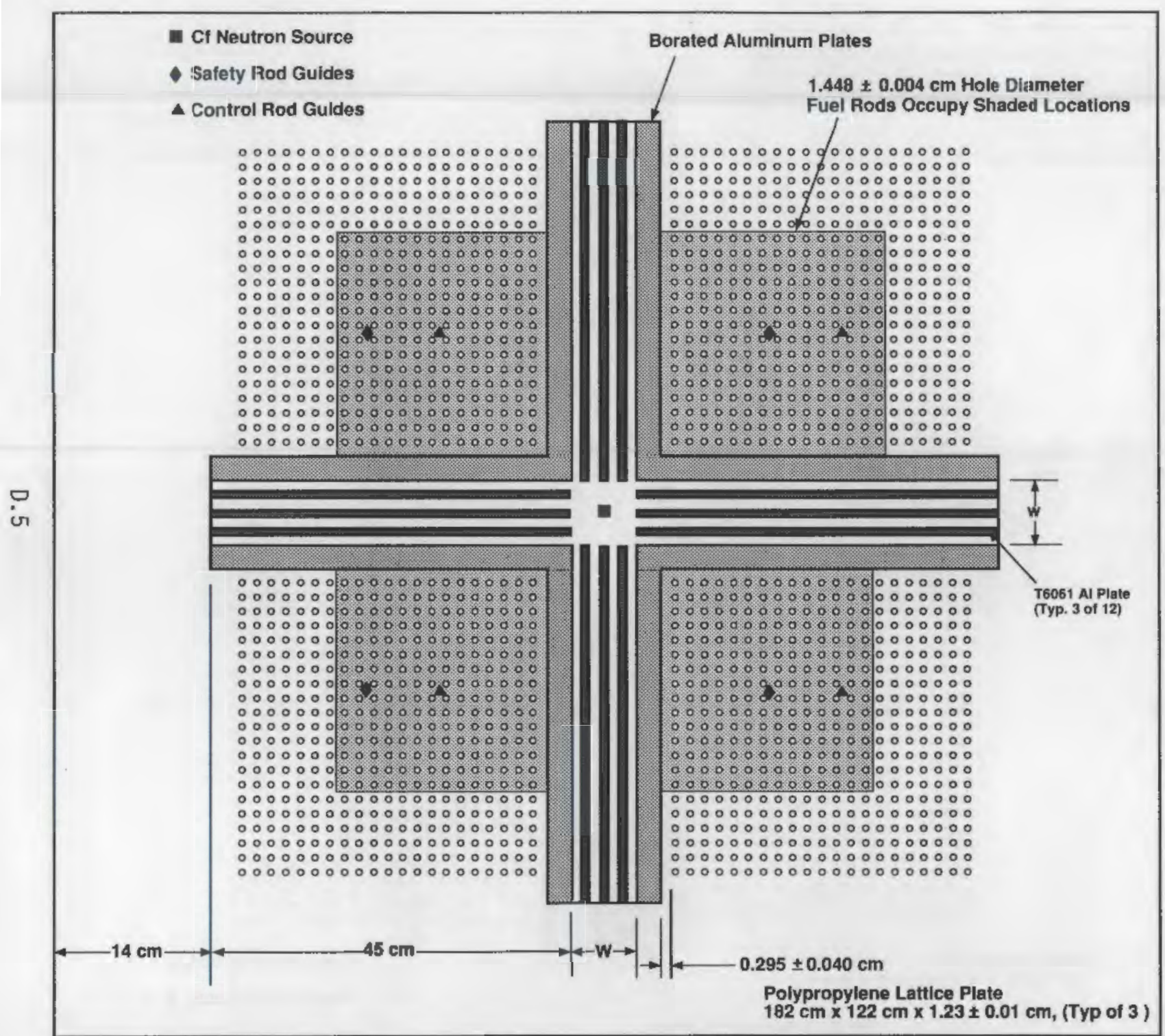

Assembly Number : $214 \mathrm{V3}$

Lattice Pitch $\quad 1.891 \pm 0.001 \mathrm{~cm}$

Safety Rods : Out of System

Fuel Rods : 855 (see comments)

$\quad: 4.31$ wt\% 235 U Enriched UO

Flux Trap Width, $w: 3.73 \pm 0.02 \mathrm{~cm}$

Plates $0.36 \pm 0.02 \mathrm{gB} / \mathrm{cm}^{2}$

Volding Materiel

: $0.63 \pm 0.001 \mathrm{~cm}$ tk Al Plate

Comments $\quad: 862.1 \pm 1.2$ Rods Predicted for Delayed Criticallity 


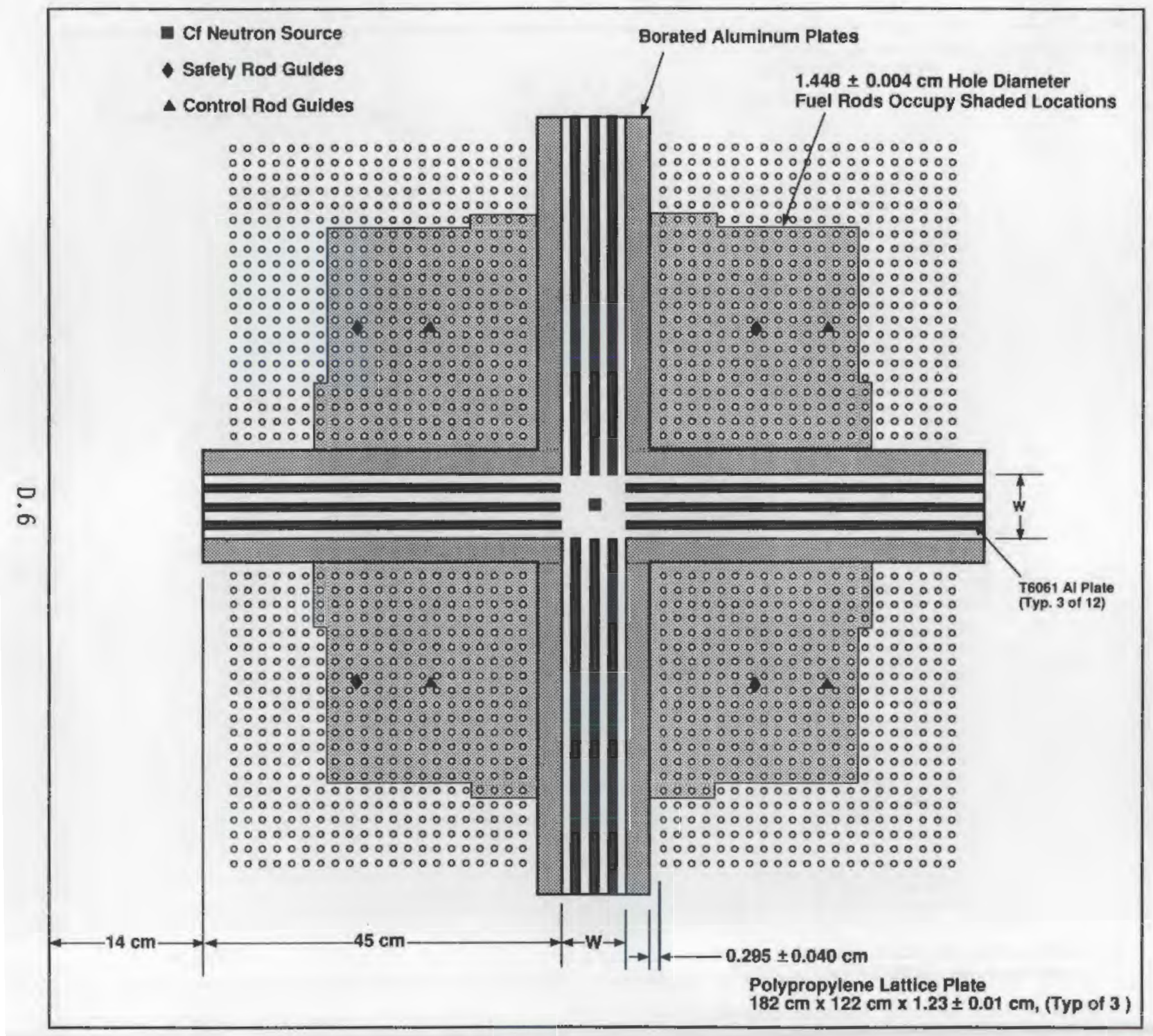

Assembly Number : $214 \mathrm{~V} 3$ (Alternant Loading)

Lattice Pitch $\quad: 1.891 \pm 0.001 \mathrm{~cm}$

Cafety Rods

Control Rods

Out of System

Fuel Rods

872 (see comments)

Fuel $\quad: 4.31$ wt\% 235 U Enriched UO

Flux Trap Width, $w: 3.73 \pm 0.02 \mathrm{~cm}$

Plates

$\begin{array}{ll}\text { Boron } & : 0.36 \pm 0.02 \mathrm{gB} / \mathrm{cm}^{2} \\ \text { Voiding Material } & : 0.63 \pm 0.001 \mathrm{~cm} \text { tk Al Plate }\end{array}$

Boral

Comments $\quad: 876.6 \pm 0.1$ Hods Predicted for

Delayed Criticallty

Polypropylene Lattice Plate 


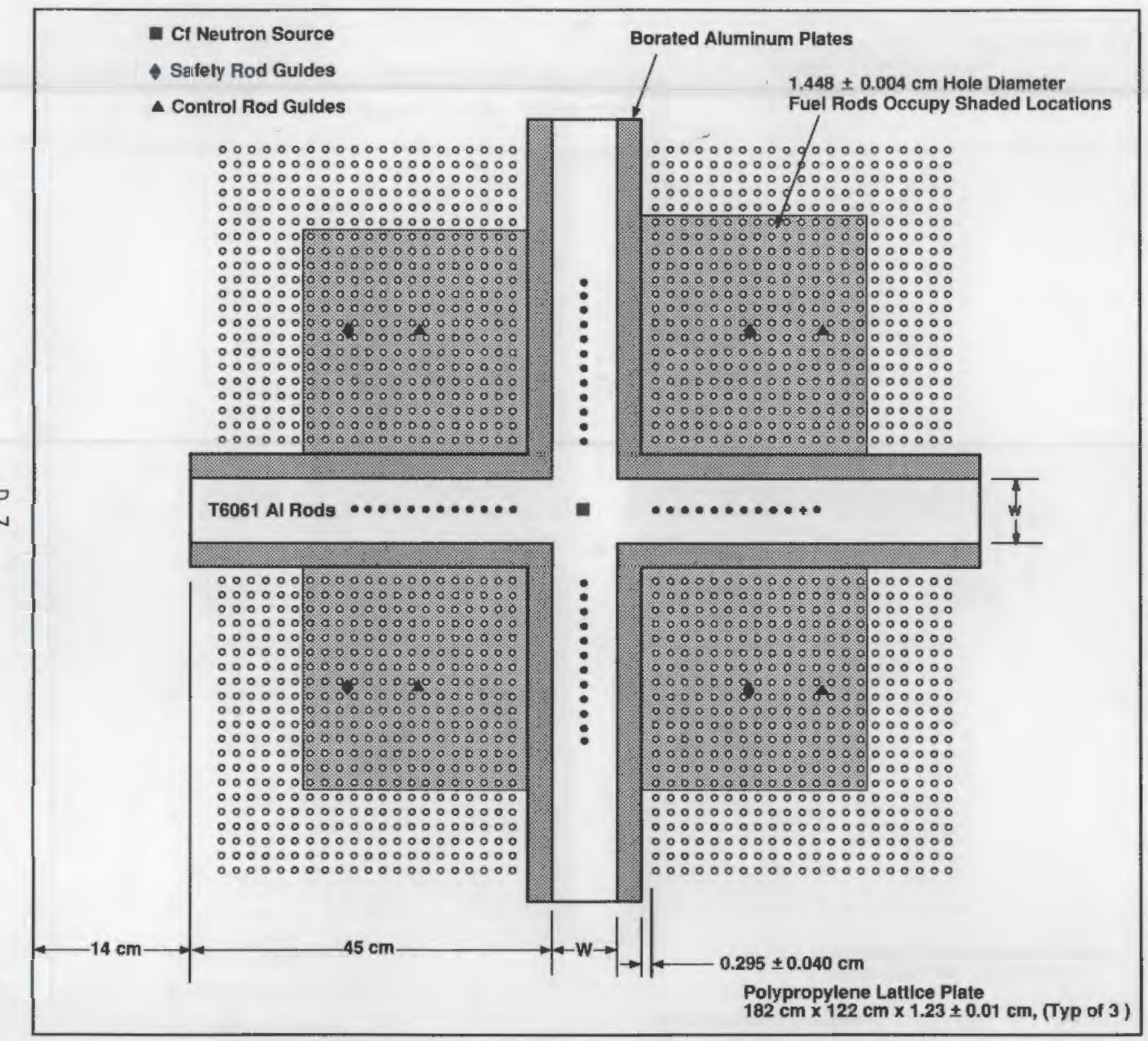

$\begin{array}{ll}\text { Assembly Number } & : 214 \mathrm{V4} \\ \text { Lattlce Pltch } & : 1.891 \pm 0.001 \mathrm{~cm} \\ \text { Safety Rods } & \text { Out of System } \\ \text { Control Rods } & \text { : Out of System }\end{array}$

Fuel Rods : :915 (see comments

Fuel $\quad: 4.31 \mathrm{wt} \%{ }^{235} \mathrm{U}$ Enriched $\mathrm{UO}_{2}$

Flux Trap Width, $W \quad: 3.73 \pm 0.02 \mathrm{~cm}$

Plates

Boron

Voiding Material

Comments

: $0.36 \pm 0.02 \mathrm{gB} / \mathrm{cm}^{2}$

$: 1.27 \pm 0.005 \mathrm{~cm}$ dia. Al Rods

925.4 \pm 1.3 Rods Predicted for

Delayed Criticality

Polypropylene Latilce Plate

$182 \mathrm{~cm} \times 122 \mathrm{~cm} \times 1.23 \pm 0.01 \mathrm{~cm}$, (Typ of 3) 


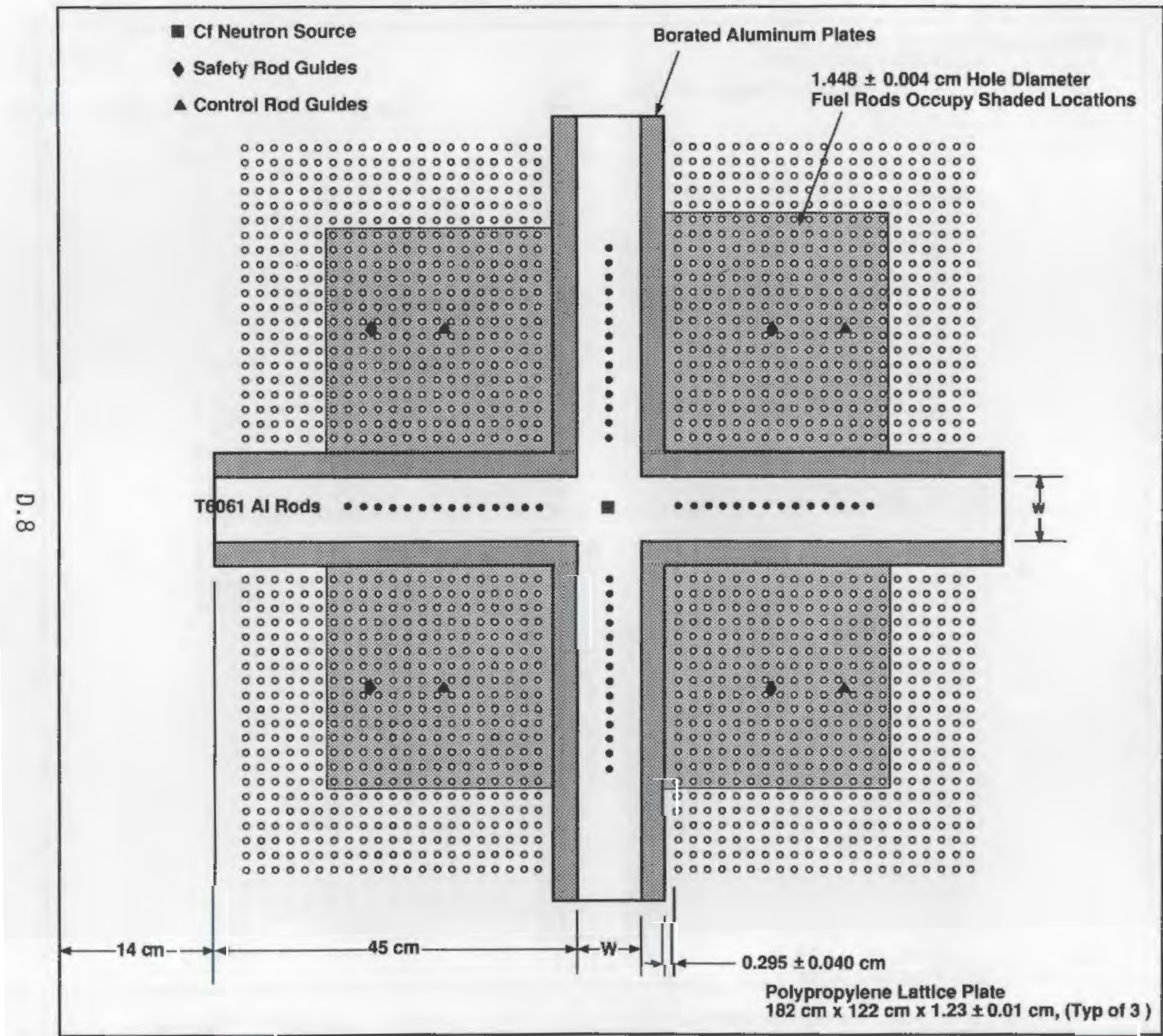

$\begin{array}{ll}\text { Assembly Number } & : 214 \mathrm{~V} 5 \\ \text { Lattice Pltch } & : 1.891 \pm 0.001 \mathrm{~cm} \\ \text { Safety Rods } & \vdots \text { Out of System } \\ \text { Control Rods } & \text { Out of System } \\ \text { Fuel Rods } & : 915 \text { (see comments) } \\ \text { Fuel } & : 4.31 \text { wt\% } 235 \mathrm{U} \text { Enriched } \mathrm{UO}_{2} \\ \text { Flux Trap Width, w } & : 3.73 \pm 0.02 \mathrm{~cm} \\ \text { Plates } & : \text { Boral } \\ \text { Boron } & : 0.36 \pm 0.02 \mathrm{gB} / \mathrm{cm}^{2} \\ \text { Voiding Material } & : 1.27 \pm 0.005 \mathrm{~cm} \text { dia. Al Rods } \\ \text { Comments } & : 924.9 \pm 1.6 \text { Rods Predicted for } \\ & \text { Delayed Criticality }\end{array}$




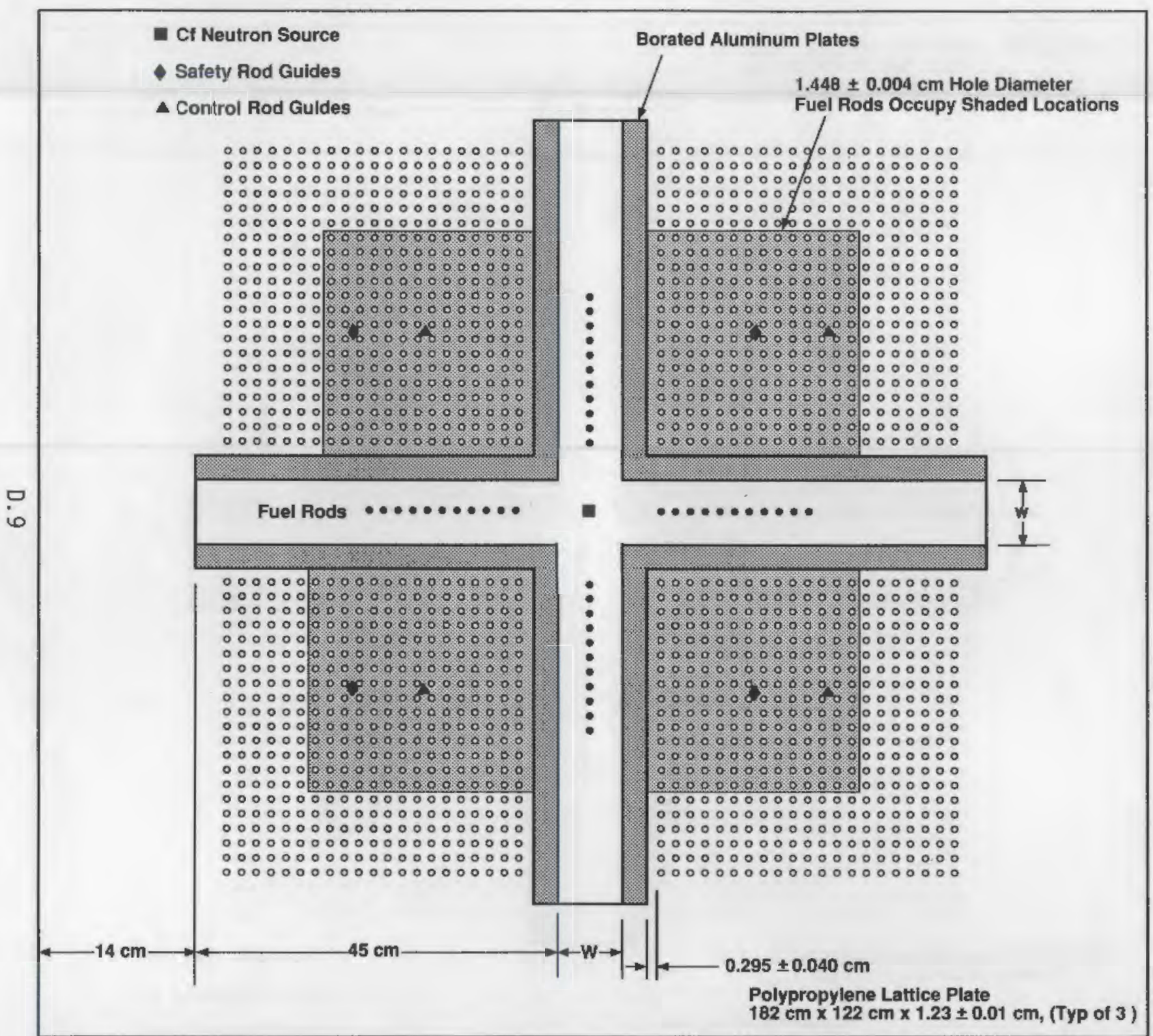

Assembly Number : 214F1

Lattice Pltch $\quad: 1.891 \pm 0.001 \mathrm{~cm}$

:Out of System

Control Rods : Out of System

Fuel Rods : 855 (see comments)

: 4.31 wt\% ${ }^{235} \mathrm{U}$ Enriched $\mathrm{UO}_{2}$

Flux Trap Width, $W: 3.73 \pm 0.02 \mathrm{~cm}$

Plates

Boron

Voiding Material Boral

Comments

$0.36 \pm 0.02 \mathrm{gB} / \mathrm{cm}^{2}$

Fuel Rods

: 873.7 \pm 1.0 Rods Predicted for Delayed Criticality (does not Include fuel in flux trap regions) 


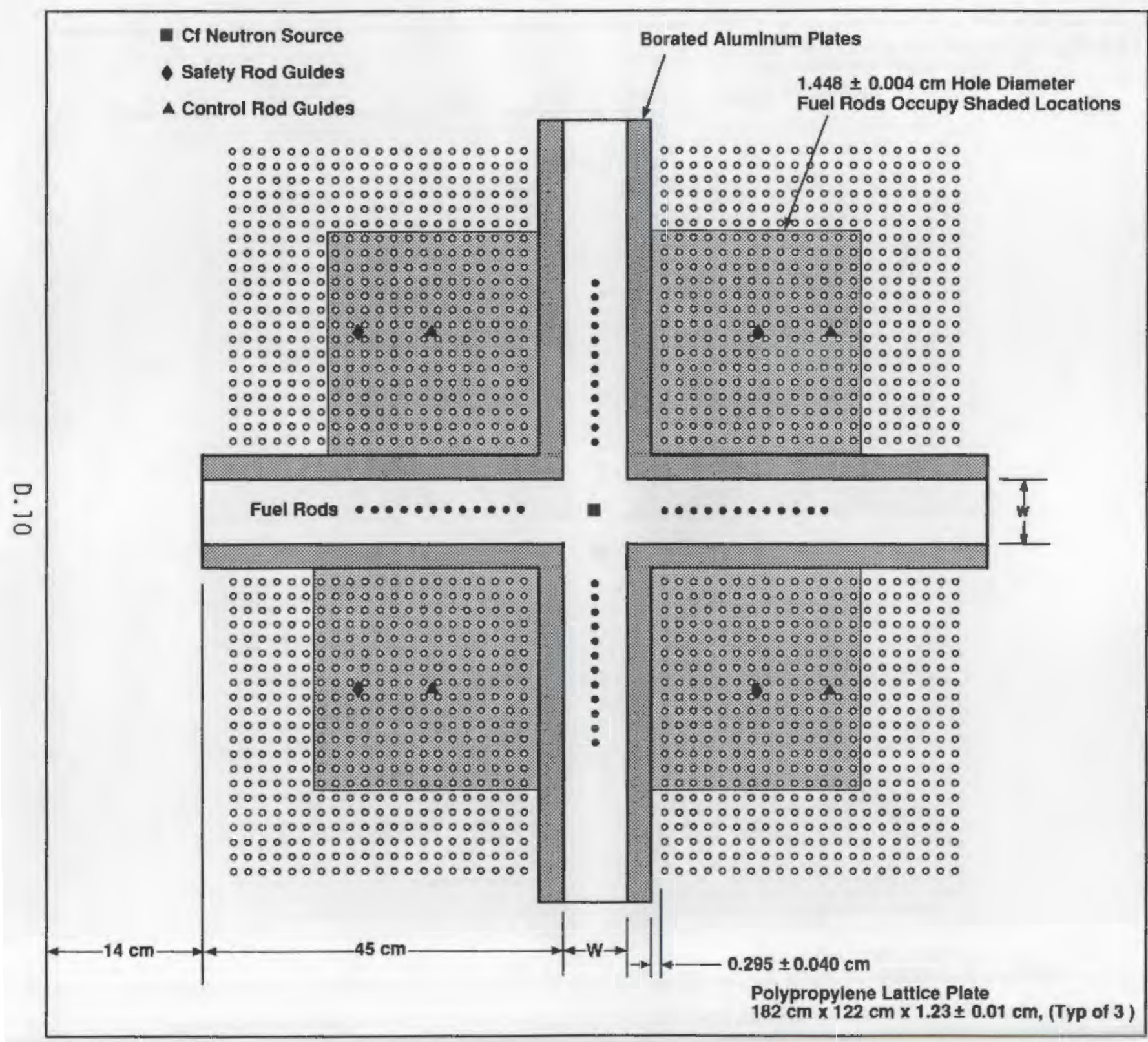

Assembly Number Lattice Pltch

Fuel Rods

Fuel

Flux Trap Width, w

Plates

Voiding Material

Comments
$214 F 2$

$1.891 \pm 0.001 \mathrm{~cm}$ Out of System Out of System

855 (see comments) 4.31 wt\% 235 U Enriched UO Boral

Borai $0.02 \mathrm{~cm}$

Fuel Rods

$866.9 \pm 3.0$ Rods Predlcted for Delayed Criticality (does not include fuel in flux trap reglons) 


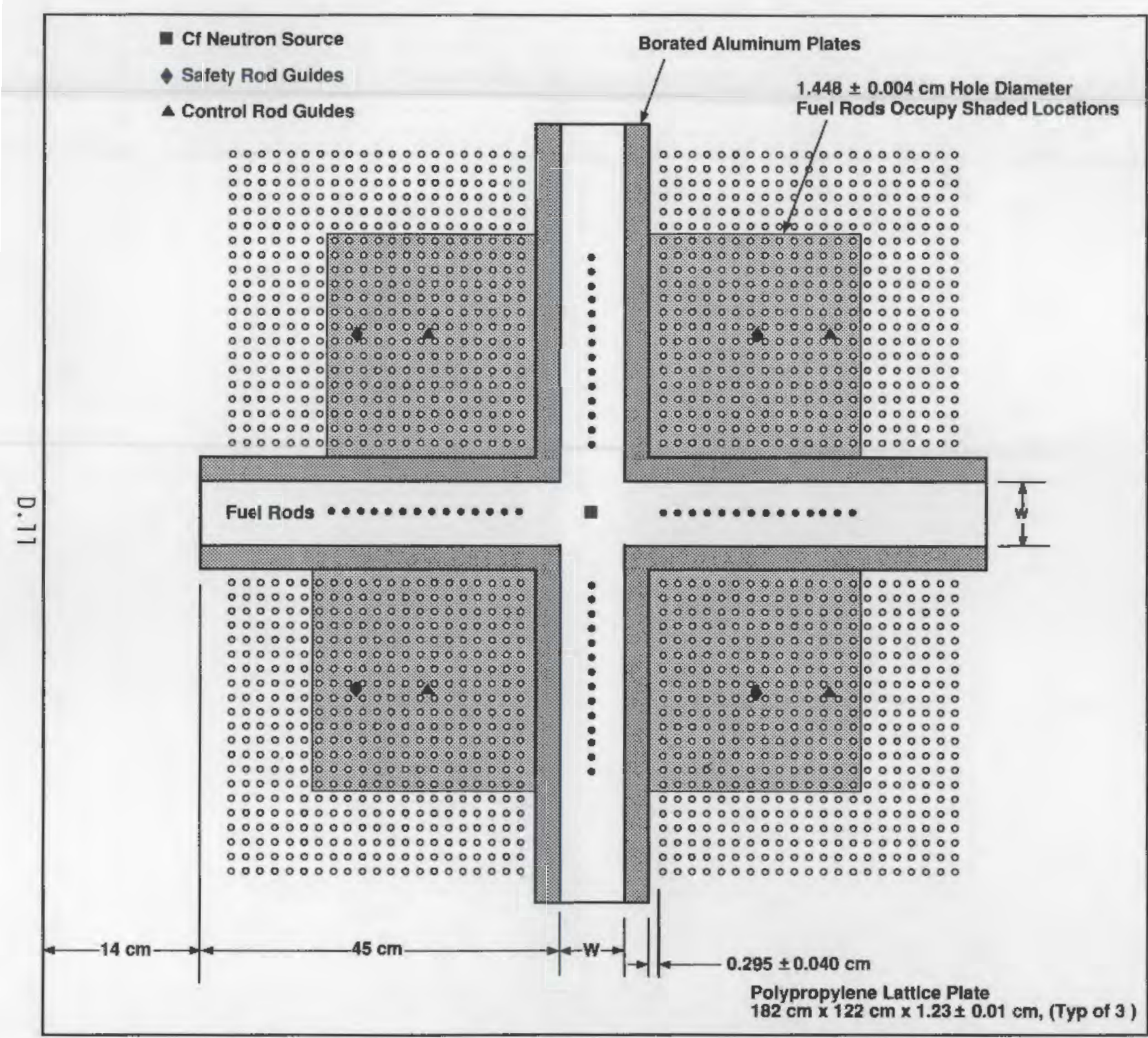

\section{Assembly Number \\ Lattice Pltch \\ Cofety Rods \\ : 214F3 \\ $: 1.891 \pm 0.001 \mathrm{~cm}$ \\ : Out of System \\ :Out of System}

Fuel Rods

Flux Trap Width, $w$

Plates

Voron Yoiding Material

Comments

: 855 (see comments)

: 4.31 wt\% ${ }^{235} \mathrm{U}$ Enriched UO $: 3.73 \pm 0.02 \mathrm{~cm}$

: Boral $0.36 \pm 0.02 \mathrm{gB} / \mathrm{cm}^{2}$

Fuel Rods

$858.5 \pm 0.1$ Rods Predicted for

Delayed Criticality (does not

include fuel in flux trap

regions) 


\section{DISTRIBUTION}

No. of

Copies

\section{OFFSITE}

12 U.S. Department of Energy

Office of Scientific \& Technical Information

Attn: DOE/OSTI-4500-R74 UC-722

Oak Ridge, TN 37830

W. Danker

U.S. Department of Energy Routing RW-32

1000 Independence Ave., SW

Washington, DC 20585

\section{R. Stein}

U.S. Department of Energy

Routing RW-30

1000 Independence Ave., SW

Washington, DC 20585

C. Kouts

U.S. Department of Energy

Routing RW-33

1000 Independence Ave., SW

Washington, DC 20585

W. Lake (3)

U.S. Department of Energy

Routing RH-33

1000 Independence Ave., SW

Washington, DC 20585

R. Kulbitskas

U.S. Department of Energy

Naval Reactors

Routing NE-60

Washington, DC 20585

F. Falci

U.S. Department of Energy

Routing DP-121

Washington, DC 20545
No. of

Copies

R. Garrison

U.S. Department of Energy

Routing DP-121

Washington, DC 20545

L. Harmon

U.S. Department of Energy

Routing DP-121

Washington, DC 20545

T. Hindman

U.S. Department of Energy

Routing DP-121

Washington, DC 20545

W. Dixon

U.S. Department of Energy Nevada Operations Office

P.0. Box 14100

Las Vegas, NV 89114-4100

E. L. Wilmot

U.S. Department of Energy

Yucca Mountain Project Office

P.0. Box 98518

Las Vegas, NV 89193-8518

J. Leonard

Office of Security Evaluations

Defense Programs - DP-4, GTN

Washington, DC 20545

J. E. Bickel

U.S. Department of Energy

Albuquerque Operations Office

Albuquerque Headquarters

P.0. Box 5400

Albuquerque, NM $\mathbf{8 7 1 1 5}$ 
No. of

Copies

G. E. Garcia

U.S. Department of Energy

ATbuquerque Operations Office

Albuquerque Headquarters

P.0. Box 5400

Albuquerque, NM 87115

K. G. Golliher

U.S. Department of Energy

Albuquerque Operations Office

Albuquerque Headquarters

P.0. Box 5400

A1buquerque, NM 87114

J. Holm

U.S. Department of Energy

Chicago Operations Office

9800 S. Cass Avenue, Bidg. 350

Argonne, IL 60439

S. Mann

U.S. Department of Energy

Chicago Operations Office

$(800$ S. Cass Avenue, B1dg. 350

Argonne, IL 60439

J. Roberts

U.S. Department of Energy

Chicago Operations Office

9800 S. Cass Avenue, B1dg. 350

Argonne, IL 60439

R. Rothman

U.S. Department of Energy

Chicago Operations office

9800 S. Cass Avenue, B1dg 350

Argonne, IL 60439

S. Hinschberger

U.S. Department of Energy

Idaho Operations office

550 Second Street

Idaho Falls, ID 83401

W. Lattin

U.S. Department of Energy

Idaho Operations office

550 Second Street

Idaho Falls, ID 83401
No. of

Copies

M. Pellechi (2)

U.S. Department of Energy

Idaho Operations office

550 Second Street

Idaho Falls, ID 83401

M. Heiskell

U.S. Department of Energy

P.0. Box E

Oak Ridge, TN 87831

J. Allen

Battelle Columbia Division

505 King Avenue

Columbus, OH 43201-2693

W. Pardue

Battelle Columbus Division

$505 \mathrm{King}$ Avenue

Columbus, $\mathrm{OH}$ 43201-2693

R. Peterson

Battelle Columbus Division

505 King Avenue

Columbus, OH 43201-2693

B. DaBelle

EG\&G Idaho, Inc.

P.0. Box 1625

Idaho Falls, ID 83145

I. Hall(4)

EG\&G Idaho, Inc.

P.0. Box 1625

Idaho Falls, ID 83145

C. V. Parks

Oak Ridge National Laboratory

P.O. Box 2008

Oak Ridge, TN 37830

R. Pope

Oak Ridge National Laboratory

P.0. Box 2008

Oak Ridge, TN 37830 
No. of

Copies

R. Raw1

Oak Ridge National Laboratory

P.0. Box 2008

Oak Ridge, TN 37830

T. Rowe

Oak Ridge National Laboratory

P.0. Box 2008

Oak Ridge, TN 37830

L. Shappert

Oak Ridge National Laboratory

P.0. 80X 2008

Oak Ridge, TN 37830

R. Westfail

Oak Ridge National Laboratory

P.0. Box 2008

Oak Ridge, TN 37830

G. E. Whitesides

Oak Ridge National Laboratory

P.0. Box 2008

Oak Ridge, TN 37830

L. E. Fisher

University of California

Lawrence Livermore Nationa] Laboratory

P.0. 80x 808

Livermore, CA 94550

P. Boiton

Roy $F$. Weston, Inc.

955 L'Enfant Plaza SW

Washington, DC 20024

M. Rahimi

Roy F. Weston, Inc.

955 L'Enfant Plaza SW

Washington, DC 20024

J. Murphy

ANEFCO, Inc.

904 Ethan Allen Hwy.

P.0. Box 433

Ridgefield, CT 06877
No. of

Copies

T. Stevens

Babcock and Wilcox

Nuclear Equipment Division

91 Stirling Avenue

Barberton, $\mathrm{OH} 44203$

R. Anderson

Chem-Nuclear System, Inc.

220 Stoneridge Drive

Columbia, SC 29210

R. Burgoyne

GA Technologies, lnc.

Building 2, Rm 644

P.0. Box 85608

San Diego, CA 92138

P. Aucoin

Nuclear Assurance Corporation 6251 Crooked Creek Road

Norcross, GA 30092

C. Johnson

Nuclear Assurance Corporation 6251 Crooked Creek Road

Norcross, GA 30092

R. Doman

Nuclear Packaging, Inc.

1010 S. 336th, Suite 220

Federal Way, WA 98003

C. Temus

Nuclear Packaging, Inc.

1010 S. 336th, Sujte 220

Federal Way, WA 98003

Bill R. Teer

Transnuclear, Inc.

Two Skyline Drive

Hawthorne, NY 10532-2120

C. Littie

Westinghouse Electric Corp.

Waste Technology Services Div.

Box 286

Madison, PA 15663-0286 
No. of

Copies

J. Siegel

U.S. Council for Energy Awareness

1776 I Street, N.W.

Washington, DC 20006

J. Kearney

Edison Electric Institute

1111 19th Street, N.W.

Washington, DC 20036

R. Lambert

Electric Power Research Institute

3412 Hillview Avenue

P.0. Box 10412

Palo Alto, CA 94304

R. Williams (9)

Electric Power Research Institute

3412 Hillview Avenue

P.0. Box 10412

Palo Alto, CA 94304

L. Trosten (5)

LeBoeuf, Lamb, Lieby, and McRae

1333 New Hampshire Avenue, N.W.

Washington, DC 20036

J. Davis

Utility Nuclear Naste Management

Group

1111 19th Street, N.W.

Washington, DC 20036

$R$. Jones

JNT, Inc.

P.0. Box 1510

Los Gatos, CA 95031-1510

R. Chappell

U.S. Nuclear Regulatory Conmission

office of Nuclear Materials

Safety and Safeguards

Nashington, DC 20555

E. Easton

U.S. Nuclear Regulatory Commission

Office of Nuclear Materials

Safety and Safeguards

Washington, DC 20555
No. of

Copies

A. Grella

U.S. Nuclear Regulatory Commission

Office of Nuclear Materials

Safety and Safeguards

Washington, DC 20555

C. Lidner

U.S. Nuclear Regulatory Commission Office of Nuclear Materials

Safety and Safeguards

Washington, DC 20555

N. Osgood

U.S. Nuclear Regulatory Cormission

Office of Nuclear Materials

Safety and Safeguards

Washington, DC 20555

C. MacDonald

U.S. Nuclear Regulatory Commission Office of Nuclear Materials

Safety and Safeguards

Washington, DC 20555

J. Roberts

U.S. Nuclear Regulatory Commission

Office of Nuclear Materials

Safety and Safeguards

Washington, DC 20555

L. Rouse

U.S. Nuclear Regulatory Commission Office of Nuclear Materials

Safety and Safeguards

Washington, DC 20555

C. Withee

U.S. Nuclear Regulatory Commission Office of Nuclear Materials

Safety and Safeguards

Washington, DC 20555

D. Hopkins

U.S. Nuclear Regulatory Colmission Office of Nuclear Materials

Safety and Safeguards

Nashington, DC 20555 
No. of

Copies

W. Lahs

U.S. Nuclear Regulatory Commission

Office of Nuclear Materials

Safety and Safeguards

Washington, DC 20555

C. Orth

U. S. Department of Transportation RRS - 32

440 Seventh Street, SW

Washington, DC 20590

\section{Wangler \\ U.S. Department of Transportation \\ Office of Materials Transportation \\ 400 Seventh Street, S.W. \\ Washington, DC 20590}

V. Pareto

Yankee Atomic Electric Co.

1617 Worcester Road

Framington, MA 01701

L. McCarten

Northern States Power CO.

414 Nicollet MaTl

Minneapolis, MN 55401

H. Shimon

Wisconsin Electric Power Co.

231 West Michigan St.

Milwaukee, WI 53201

K. Folk

Southern Company Services

P.0. Box 1625

Birmingham, AL 35202

D. Frech

Duke Power Company

P.0. Box 33189

Charlotte, NC 28242

B. Rasmussen

Duke Power Company

P.0. Box 33189

Charlotte, NC 28242
No. of

Copies

\author{
W. B. Andrews \\ Science Applications International \\ Corporation \\ Nevada Nuclear Waste Storage \\ Investigations \\ Valley Bank Center \\ 101 Convention Center Drive \\ Las Vegas, NV 89109 \\ D. Brodnick \\ Florida Power \& Light Co. \\ P.O. Box 14000 \\ Juno Beach, F] 33408 \\ J. Fisher \\ Virginia Power Company \\ P.0. Box 2666 \\ Richmond, VA 23261 \\ M. Smith \\ Virginia Power Company \\ P.0. Box 2666 \\ Richmond, VA 23261
}

J. Ladesich

Southern California Edison Co.

2244 Walnut Grove Avenue

Rosemead, CA 91770

L. Friel

Western Interstate Energy Board 3333 Quebec Street

Denver, CO 80207

Douglas Larson, Exec. Dir. Western Interstate Energy Board 3333 Quebec Street

Denver, CO 80207

Ken Nemeth, Exec. Dir.

Southern States Energy Board 3091 Governors Lakes Drive Suite 400

Norcross, GA 30071 
No. of

Copies

Barbara Foster

National Conference of State Legislatures

Energy Science and Natural Resources

1050 17th Street, Suite 2100

Denver, CO $\mathbf{8 0 6 2 5}$

\section{Gail Chehak}

National Congress of Indian $\mathrm{Ch}$. 900 Pennsylvania S.E. Washington, DC 20003

G. C. Allen

Sandia National Laboratory Division 6322

Albuquerque, NM 87185

P. W. Dean

Sandia National Laboratory

Division 8024

A1buquerque, NM 87185

R. E. Glass

Sandia National Laboratory

Division 6322

Albuquerque, NM 87185

D. L. Hartley

Sandia National Laboratory

Division 6000

Albuquerque, NM 87185

W. I. Klein (3)

Sandia National Laboratory

Division 3151

A7buquerque, NM 87185

S. A. Landerberger (5)

Sandia Nationa1 Laboratory

Division 3141

A1buquerque, NM 87185

R. E. Luna

Sandia National Laboratory

Division 6321

A1buquerque, NM 87185
No. of

Copies

R. H. Lynch

Sandia Nationa] Laboratory

Division 6300

Albuquerque, NM 87185

TC Library (25)

Attn: ПC Master File

Sandia Nationa? Laboratory

Division 6320

Albuquerque, NM 87185

T. L. Sanders

Sandia National Laboratory

Division 6322

A1buquerque, NM 87185

J. E. Stiegler

Sandia National Laboratory

Division 6320

A1buquerque, NM 87185

C. Hard (8)

Sandia National Laboratory

Division 3141-1

Albuquerque, NM 87185

M. M. Warrant

Sandia National Laboratory

Division 6323

Albuquerque, NM 87185

\section{FOREIGN}

A. Charlier

Belgonucleaire

25 rue du Champf de Mars

B-1050 Bruxelles

BELGIUM

M. Doucet

Belgonucleaire

25 rue du Champf de Mars

B-1050 Bruxelles

BELGIUM 
No. of

Copies

M. Ermont

Centre de'Etudes Nucleaires

B.P. 6

F-92260 Fontenay-aux-Roses

FRANCE

L. Maubert

Centre de'Etudes Nucleaires

B.P. 6

F-92260 Fontenay-aux-Roses

FRANCE

G. Poullot

Centre de'Etudes Nucleaires

B.P. 6

F-92260 Fontenay-aux-Roses

FRANCE

L. M. Farrington

British Nuclear Fuels PLC

Technical Services

R101 Ruterford House

Risleyk, Warrington WA3 6 AS

UNITED KINGDON

Mr. G. F. Gualdrini

Comitato Nazionale

per la Ricerca e per lo Sviluppo

Dellenergia Nucleare

E. Delle Energie Alternative

Via G. Mazzini 2

40138 Bologna

ITALY

G. Kame 1 ander

Oesterr Forschungszentrum

Seibersdorf Ges. m.b.H.

Lenaugasse 10

A-1082 Vienna

AUSTRIA

R. Keay

British Nuclear Fuels PLC

Technical Services

R101 Ruterford House

Risley, Narrington WA3 6 AS

UNITED KINGDOM
No. of

Copies

Tomozo Koyama

PNC, Power Reactor \& Nuclear Fuel Development Corporation

1-9-13, Akasaka

Minato-Ku, Tokyo

JAPAN

P. Landeyro

ENEA, CRE-Casaccia

1-00100 Roma

ITALY

Mr. S. Mancioppi

Comitato Nazionale per l'Energia Nucleare

Viale Regina Margherita 125

I-00100 Roma

ITALY

T. Matsumoto

Power Reactor and Nuclear Fuel

Development Corporation

1-9-13 Akasaku

Minatoku, Tokyo

JAPAN

D. Mennerdah1

$A B$ Erling Mennerdah]

Pl 457

S-186 99 Vallentuna

SWEDEN

Y. Naito

JAERO - Nuclear Fuel Facility

Evaluation Laboratory

Nuclear Safety Research Centre

Tokai ura, Naka-gun

Ibaraki-ken 319-11

JAPAN

Mr. J. M. Paratte

Federal Institute for Reactor Research

CH-5303 Wurenlingen

SWITZERLAND 
No. of

Copies

Enrico Sartori

OECD

NEA Data Bank

91191 Gif-sur-Yvette CEDEX FRANCE

H. H. Schweer

Physikal Isch-Technische Bundesanstalt

Bundesallee 1000-3300 Braunschweig FEDERAL REPUBLIC OF GEPMANY

\section{G. Walker}

Safety and Reliability Directorate

UK Atomic Energy Authority

Culcheth, Warrington NH3 4NE

Royaume-Uni

UNITED KINGDOM

Mr. F. Wasastjerna

Technical Research Center of Finl and

Nuclear Engineering Laboratory

P.0. Box 169

SF-00191 Helsinki

FINLAND
No. of

Copies

Mr. W. Weber

Gesellschaft fur Reaktorsicherheit

Forschungsgel ande

0-8046 Garching bei Munchen

FEDERAL REPUBLIC OF GERMANY

\section{ONSITE}

3 DOE Richland Operations Office

C. E. Collantes

D. C. Langstaff

J. Peterson

Westinghouse Hanford Company

C. L. Brown

24 Pacific Northwest Laboratory

G. Beeman

S. R. Bierman (10)

E. D. Clayton

M. A. Covert

J. Creer

A. L. Doherty

S. W. Heaberlin

R. A. Libby

R. C. Lloyd

Publishing Coordination

Technical Report File (5) 